\title{
Parvalbumin, Calbindin, or Calretinin in Cortically Projecting and GABAergic, Cholinergic, or Glutamatergic Basal Forebrain Neurons of the Rat
}

\author{
IVANA GRITTI, ${ }^{1}$ IAN D. MANNS, ${ }^{2}$ LYNDA MAINVILLE, ${ }^{2}$ AND BARBARA E. JONES ${ }^{2 *}$ \\ ${ }^{1}$ Dipartimento di Scienze Cliniche L. Sacco, Università degli Studi di Milano, \\ 20157 Milan, Italy \\ ${ }^{2}$ Department of Neurology and Neurosurgery, McGill University, Montreal Neurological \\ Institute, Montreal, Quebec H3A 2B4, Canada
}

\begin{abstract}
The basal forebrain (BF) plays an important role in modulating cortical activity and facilitating processes of attention, learning, and memory. This role is subserved by cholinergic neurons but also requires the participation of other noncholinergic neurons. Noncholinergic neurons include $\gamma$-amino butyric acidergic (GABAergic) neurons, some of which project in parallel with the cholinergic cells to the cerebral cortex, others of which project caudally or locally. With the original aim of distinguishing different subgroups of GABAergic neurons, we examined immunostaining for the calcium binding proteins (CBPs) parvalbumin (Parv), calbindin (Calb), and calretinin (Calret) in the rat. Although the $\mathrm{CBP}^{+}$cell groups were distributed in a coextensive manner with the GABAergic cells, they were collectively more numerous. Of cells retrogradely labeled with cholera toxin (CT) from the prefrontal or parietal cortex, $\mathrm{Parv}^{+}$and $\mathrm{Calb}^{+}$cells, but not Calret ${ }^{+}$cells, represented substantial proportions $(\sim 35-45 \%$ each $)$ that collectively were greater than that of GABAergic projection neurons. From dual immunostaining for the CBPs and glutamic acid decarboxylase (GAD), it appeared that the vast majority $(>90 \%)$ of the Parv ${ }^{+}$group was $\mathrm{GAD}^{+}$, whereas only a small minority $(<10 \%)$ of the $\mathrm{Calb}^{+}$or $\mathrm{Calret}^{+}$group was $\mathrm{GAD}^{+}$. Significant proportions of $\mathrm{Calb}^{+}(>40 \%)$ and $\mathrm{Calret}^{+}(>80 \%)$ neurons were immunopositive for phosphate-activated glutaminase, the synthetic enzyme for transmitter glutamate. The results suggested that, whereas Calret ${ }^{+}$cells predominantly comprise caudally or locally projecting, possibly glutamatergic BF neurons, Parv $^{+}$cells likely comprise the cortically projecting GABAergic $\mathrm{BF}$ neurons and $\mathrm{Calb}^{+}$cells the cortically projecting, possibly glutamatergic $\mathrm{BF}$ neurons that would collectively participate with the cholinergic cells in the modulation of cortical activity. J. Comp. Neurol. 458:11-31, 2003. ๑ 2003 Wiley-Liss, Inc.
\end{abstract}

Indexing terms: calcium binding proteins; medial septum-diagonal band; substantia innominata; preoptic nuclei

The basal forebrain (BF) plays a critical role in the modulation of cortical activity across sleep-wake states (for review, see Jones, 2000). Constituent cholinergic neurons stimulate cortical activation during waking and paradoxical sleep and play an important role in the processes of attention, learning, and memory (Metherate et al., 1988, 1992; Smith, 1988; Huerta and Lisman, 1993; Jones, 1993; Muir et al., 1994; Kilgard and Merzenich, 1998; Cape and Jones, 2000; Cape et al., 2000). In addition to cholinergic cells, other neurons constitute important elements of the BF cell population. Among these, $\gamma$-amino butyric acidergic (GABAergic) neurons are twice as numerous and more heterogeneous than the cholinergic neurons (Brashear et al., 1986; Kiss et al., 1990a; Gritti et al., 1993). Relatively small GABAergic neurons project cau- dally and most probably locally (Gritti et al., 1994) to the diencephalon and brainstem, and relatively large

Grant sponsor: Canadian Institutes of Health Research; Grant number: 13458; Grant sponsor: National Institute of Mental Health; Grant number: RO1 MH60119-01A1; Grant sponsor: Canadian Natural Science and Engineering Research Council.

*Correspondence to: Barbara E. Jones, Montreal Neurological Institute, 3801 University Street, Montreal, Quebec H3A 2B4, Canada.

E-mail: barbara.jones@mcgill.ca

Received 10 August 2002; Revised 30 August 2002; Accepted 27 September 2002

DOI 10.1002/cne.10505

Published online the week of February 3, 2003 in Wiley InterScience (www.interscience.wiley.com). 
GABAergic neurons project in parallel with the cholinergic neurons to the cerebral cortex (Gritti et al., 1997). Subgroups of GABAergic neurons projecting to different targets may play different roles in the modulation of cortical activity and behavioral state (for review, see Jones and Muhlethaler, 1999). Multiple subgroups of GABAergic neurons have been distinguished by their morphology, projections, and physiology in the neocortex and hippocampus. These have also been found to differ in their content of the calcium binding proteins (CBPs) parvalbumin (Parv), calbindin-D28k (Calb), and calretinin (Calret) that has accordingly provided a means to distinguish them by immunohistochemical staining (Celio, 1986; Kawaguchi and Hama, 1988; Kawaguchi and Kubota, 1993; Freund and Buzsaki, 1996; DeFelipe, 1997). In the neocortex and hippocampus, these CBPs are contained within largely nonoverlapping groups of nonpyramidal GABAergic interneurons. Within the $\mathrm{BF}$ of the rat, the CBPs have been visualized in noncholinergic, presumed GABAergic neurons (Celio, 1990; Kiss et al., 1990a, 1997; Chang and Kuo, 1991; Zaborszky et al., 1999). In the medial septum-diagonal band nuclei, Parv-containing neurons have been shown to correspond to the septohippocampal projection GABAergic neurons (Freund, 1989; Kiss et al., 1990b), whereas Calret-containing neurons appeared to correspond to locally or caudally projecting presumed GABAergic neurons (Kiss et al., 1997). The CBPs thus appeared to be a useful tool for identifying and distinguishing different subgroups of noncholinergic, presumed GABAergic neurons in the BF.

The original aims of the present study were to determine in the rat brain whether the CBPs are contained within subgroups of GABAergic BF neurons and to investigate which $\mathrm{CBP}(\mathrm{s})$ is (are) contained within the cortically projecting GABAergic neurons. With immunoperoxidase staining, we examined the distribution of all Parv-, Calb-, and Calret-immunostained neurons and the distribution of those projecting to the prefrontal or parietal cortex visualized by retrograde transport of cholera toxin (CT). Given unanticipated larger numbers of CBP-containing neurons as compared with GABAergic neurons (Gritti et al., 1993, 1997) in estimated total and cortically projecting cell contingents, we subsequently examined the colocalization of the CBPs with the synthetic enzyme for GABA, glutamic acid decarboxylase (GAD), by dual-immunofluorescent staining. We also investigated whether Calb might be colocalized with choline acetyl transferase (ChAT) in the rat brain, as documented in the monkey brain (Chang and Kuo, 1991). We also examined whether CBPs might be colocalized with glutamate by dual immunostaining for phosphate activated glutaminase (PAG), the synthetic enzyme for the transmitter pool of glutamate (Kaneko and Mizuno, 1988, 1994; Akiyama et al., 1990; Kaneko et al., 1992; Manns et al., 2001). We previously presented some of the results in abstract form (Gritti et al., 1999, 2001).

\section{MATERIALS AND METHODS Animals and surgery}

Fourteen adult male Wistar rats (Charles River, St. Constant, Canada), weighing approximately $250 \mathrm{~g}$ were used in this study. The rats were anesthetized with sodium pentobarbital (Somnotol, 60-67 mg/kg, intraperito-

Abbreviations

$\begin{array}{ll}\text { AAA } & \text { anterior amygdaloid area } \\ \text { ac } & \text { anterior commissure } \\ \text { Acb } & \text { nucleus accumbens } \\ \text { AHA } & \text { anterior hypothalamic area } \\ \text { AM } & \text { anteromedial thalamic nucleus } \\ \text { AO } & \text { anterior olfactory nucleus } \\ \text { BF } & \text { basal forebrain } \\ \text { BLA } & \text { basolateral amygdaloid nucleus } \\ \text { BST } & \text { bed nucleus of the stria terminalis } \\ \text { CeA } & \text { central amygdaloid nucleus } \\ \text { Cg1 } & \text { cingulate cortex, area1 } \\ \text { Cg3 } & \text { cingulate cortex, area } 3 \\ \text { CL } & \text { centrolateral thalamic nucleus } \\ \text { CM } & \text { centromedial thalamic nucleus } \\ \text { CPu } & \text { caudate putamen } \\ \text { DBB } & \text { diagonal band of Broca nucleus } \\ \text { DHA } & \text { dorsal hypothalamic area } \\ \text { EP } & \text { entopeduncular nucleus } \\ \text { f } & \text { fornix } \\ \text { Fr1 } & \text { frontal cortex, area 1 } \\ \text { Fr2 } & \text { frontal cortex, area } 2 \\ \text { FL } & \text { Forelimb area of the cortex } \\ \text { FStr } & \text { fundus striati } \\ \text { GP } & \text { globus pallidus } \\ \text { IAM } & \text { interanteromedial thalamic nucleus } \\ \text { ic } & \text { internal capsule } \\ \text { IL } & \text { infralimbic cortex } \\ \text { IMD } & \text { intermediodorsal thalamic nucleus } \\ \text { LH } & \text { lateral hypothalamic area } \\ \text { LHa } & \text { anterior lateral hypothalamic area } \\ \text { LO } & \text { lateral orbital cortex } \\ \text { LOT } & \text { lateral olfactory tract nucleus } \\ \text { LPOA } & \text { lateral preoptic area } \\ \text { LS } & \text { lateral septum } \\ & \end{array}$

$\begin{array}{ll}\text { MCPO } & \text { magnocellular preoptic nucleus } \\ \text { MD } & \text { mediodorsal thalamic nucleus } \\ \text { MeA } & \text { medial amygdaloid nucleus } \\ \text { MO } & \text { medial orbital cortex } \\ \text { MPA } & \text { medial preoptic area } \\ \text { MS } & \text { medial septum } \\ \text { mt } & \text { mammillothalamic tract } \\ \text { oc } & \text { optic chiasm } \\ \text { ot } & \text { optic tract } \\ \text { OTu } & \text { olfactory tubercle } \\ \text { Par1 } & \text { parietal cortex, area1 } \\ \text { Par2 } & \text { parietal cortex, area } 2 \\ \text { PaV } & \text { paraventricular hypothalamic nucleus } \\ \text { PC } & \text { paracentral thalamic nucleus } \\ \text { Pir } & \text { piriform cortex } \\ \text { PO } & \text { posterior thalamic nuclear group } \\ \text { POAH } & \text { preoptic-anterior hypothalamic region } \\ \text { PT } & \text { paratenial thalamic nucleus } \\ \text { PV } & \text { paraventricular thalamic nucleus } \\ \text { Re } & \text { reuniens thalamic nucleus } \\ \text { Ret } & \text { reticular thalamic nucleus } \\ \text { Rh } & \text { rhomboid thalamic nucleus } \\ \text { SCh } & \text { suprachiasmatic nucleus } \\ \text { SIa } & \text { substantia innominata pars anterior } \\ \text { SIp } & \text { substantia innominata pars posterior } \\ \text { Sm } & \text { stria medullaris } \\ \text { SO } & \text { nucleus supraopticus } \\ \text { VLO } & \text { ventrolateral orbital cortex } \\ \text { VM } & \text { ventromedial thalamic nucleus } \\ \text { VMH } & \text { ventromedial hypothalamic nucleus } \\ \text { VO } & \text { ventral orbital cortex } \\ \text { VPL } & \text { ventral posterolateral thalamic nucleus } \\ \text { VPM } & \text { ventral posteromedial thalamic nucleus } \\ & \end{array}$


neally) for all surgical procedures and for perfusion. The McGill University Animal Care Committee and the Canadian Council on Animal Care approved all procedures.

For the study of the CBP-containing cells that project to the cerebral cortex with the use of immunoperoxidase techniques, eight rats were first operated on under general anesthesia for injection of the retrograde tracer, CT b subunit (choleragenoid; LIST Biological Laboratories, Campbell, CA). The tracer was placed into the prefrontal cortex in four rats (CT22, CT25, CT26, and CT27) and into the parietal cortex in four rats (CT24, CT29, CT30, and CT31). Injections were performed under stereotaxic guidance according to coordinates for the right prefrontal cortex: anterior-posterior (AP), +11.5; vertical (V), +5.5; lateral (L), -0.75 (with reference to ear bar zero); and for the right parietal cortex: $\mathrm{AP},-1.0 ; \mathrm{V},-3.0 ; \mathrm{L},-4.6$ (with reference to bregma; see Paxinos and Watson, 1986). CT was dissolved as a $1 \%$ solution in Tris buffer $(\mathrm{pH} 7.5)$ and injected in a volume of $100 \mathrm{nl}$ over 5-10 minutes through a 1- $\mu$ l Hamilton microsyringe that was fitted with an oil-filled micropipette with a tip diameter of $50-100 \mu \mathrm{m}$. Two rats (CT22 and CT24) also received colchicine treatment approximately 24 hours after the CT injections and approximately 24 hours before death. All rats were killed under anesthesia by perfusion with a paraformaldehyde fixative approximately 48 hours after the CT injections.

For the study of the colocalization of CBPs and the transmitter enzymes using immunofluorescent staining, six rats were used (CT80, CT81, CT82, CT83, PP1, and PP2), four of which (CT80, CT81, CT82, CT83) received colchicine treatment approximately 24 hours before death and were killed under anesthesia by perfusion with a Zamboni fixative.

As previously described (Gritti et al., 1997), colchicine (Sigma, St. Louis, MO) was injected in a dose of $50 \mu \mathrm{g}$ in $25 \mu \mathrm{l}$ of saline solution into the left ventricle of anesthetized rats according to stereotaxic procedures (coordinates AP $-0.8, \mathrm{~V}-4.4, \mathrm{~L}+1.5$, with reference to bregma). Colchicine was found to enhance GAD immunostaining within nerve cell bodies but to not alter that of CBPs for which it was deemed unnecessary. Although it was also found to be unnecessary for revealing GAD when using the anti-GAD67 antibody in paraformaldehyde-fixed tissue (Gritti et al., 1997), colchicine was important for revealing GAD with this antibody in the Zamboni-fixed tissue used for the immunofluorescent staining of PAG.

\section{Perfusion and fixation}

Brains used for immunoperoxidase staining of CBP and CT (from eight rats) were fixed with a paraformaldehyde solution. After a brief rinse with phosphate buffered saline $(0.1 \mathrm{M}$, containing $20 \mathrm{mM} \mathrm{MgCl}$, $\mathrm{pH} 7.4)$, the animals were perfused through the ascending aorta with $1,000 \mathrm{ml}$ of 3\% paraformaldehyde in $0.1 \mathrm{M}$ phosphate buffer $(\mathrm{pH} 7.4$ over $\sim 30$ minutes), followed by $10 \%$ sucrose in phosphate buffer (pH 7.4, over $\sim 15$ minutes), as previously described (Gritti et al., 1993, 1997). The brains were removed and immersed overnight in 30\% sucrose in phosphate buffer for cryoprotection. Brains were subsequently frozen at $-50^{\circ} \mathrm{C}$ with isopentane and stored at $-80^{\circ} \mathrm{C}$.

Brains used for immunofluorescent staining of $\mathrm{CBP}$ and GAD, PAG, or ChAT (from six rats) were fixed with Zamboni's solution, according to a slight modification of the procedure developed by Kaneko and colleagues for immunostaining of the PAG enzyme (Kaneko and Mizuno, 1988;
Kaneko et al., 1989; Manns et al., 2001). After a brief rinse with phosphate buffered saline, the animals were perfused through the ascending aorta with $500 \mathrm{ml}$ of a modified Zamboni's solution containing $0.3 \%$ paraformaldehyde and $75 \%$ saturated picric acid in $0.1 \mathrm{M}$ sodium phosphate buffer ( $\mathrm{pH} 7.0$, over $\sim 30$ minutes). The brains were postfixed overnight at $4^{\circ} \mathrm{C}$ in a solution of $3 \%$ paraformaldehyde with $75 \%$ saturated picric acid. Brains were subsequently immersed in a solution of $30 \%$ sucrose at $4^{\circ} \mathrm{C}$ for approximately 48 hours for cryoprotection. Brains were then frozen at $-50^{\circ} \mathrm{C}$ and stored at $-80^{\circ} \mathrm{C}$.

\section{Immunohistochemistry}

Immunoperoxidase staining. Brains processed for immunoperoxidase staining (by L.M.) of CBP and CT were cut in the coronal plane on a freezing microtome at a thickness of $25 \mu \mathrm{m}$ (CT22 and CT24) or $20 \mu \mathrm{m}$ (CT25, CT26, CT27, CT29, CT30, and CT31). Sections were collected at $400-\mu \mathrm{m}$ intervals in phosphate buffer $(\mathrm{pH} 7.4,0.1$ M) to produce 16 or 20 adjacent series.

With the peroxidase-antiperoxidase (PAP) technique employed previously (Gritti et al., 1997), adjacent series from several brains were processed for single or dual immunostaining of the CBPs and CT. Single-immunostained series were processed for Parv (CT22, CT24, and CT25), Calb (CT22, CT24, and CT25), or Calret (CT29 and CT30). For Parv, a monoclonal antibody from mouse (Sigma) was used at a dilution of 1:1,000; for Calb, a monoclonal antibody from mouse (Sigma) was used at a dilution of 1:200; and for Calret, a polyclonal antibody from rabbit (Chemicon International, Temecula, CA) was used at a dilution of $1: 10,000$. Sections were incubated in the primary antibodies overnight at room temperature. They were subsequently placed for 30 minutes in an anti-mouse (for Parv and Calb) or anti-rabbit (for Calret) secondary antibody (both from donkey, diluted 1:50 or 1:100, respectively; Jackson Immuno Research, West Grove, PA) and then for 30 minutes in mouse or rabbit PAP (diluted 1:200; Jackson Immuno Research). PAP was revealed by $3,3^{\prime}$ diaminobenzidine (DAB) in the presence of $0.1 \%$ glucose oxidase for 14 minutes at room temperature. Adjacent series of sections were processed with sequential, dualimmunoperoxidase staining for CT and one CBP, according to previously published procedures (Gritti et al., 1994, 1997). Sections were incubated overnight in goat anticholeragenoid antiserum (at a dilution of 1:40,000; LIST Biological Laboratories). They were subsequently placed in an anti-goat antiserum (from donkey at 1:100) and goat PAP (1:200; both from Jackson Immuno Research). PAP was revealed with $\mathrm{DAB}$ using nickel intensification in the presence of $0.01 \% \mathrm{H}_{2} \mathrm{O}_{2}$ for 6 minutes or in the presence of $0.1 \%$ glucose oxidase for 15 minutes (in CT22 and CT24). After prolonged rinsing, series of sections were incubated for dual immunostaining with one of the CBP antibodies: the mouse antibody for Parv (1:1,000; in all brains), the mouse antibody for Calb (1:200; in CT22, CT24, CT25, CT26, CT27, and CT31), or the rabbit antiserum for Calret (1:10,000; in CT29 and CT30), as described above. PAP was revealed by using $\mathrm{DAB}$ in the presence of $0.1 \%$ glucose oxidase in Tris buffer ( $\mathrm{pH} 7.4$ ) for 13-15 minutes at room temperature.

In all single- or dual-immunoperoxidase staining procedures, a Tris saline solution (TS; $0.1 \mathrm{M}$ ) containing normal donkey serum at $1 \%$ concentration was used for diluting the primary antibody and for rinsing, and one containing 
normal donkey serum at $6 \%$ was used for blocking before incubations. Controls were routinely run with every procedure by omitting the primary antibodies and for antisera, replacing them with normal sera from the same species to ensure that nonspecific staining due to crossreactivity was not occurring. At the end of processing, all sections were washed in phosphate buffer, mounted out of water, dehydrated, and coverslipped with Permount (Fisher Scientific, Fairlawn, NJ).

Immunofluorescent staining. To assess dual immunostaining for the CBPs and GAD, PAG, or ChAT enzyme proteins (EPs), we found that immunoperoxidase techniques were not suitable due to the colocalization of the CBPs and EP in the cytoplasm of the cells and thus used immunofluorescent staining (by L.M. and I.D.M.) in six brains (CT80, CT81, CT82, CT83, PP1, and PP2). Sections were cut on a freezing microtome at $20 \mu \mathrm{m}$ thickness, and 20 adjacent series of sections were collected at $400-\mu \mathrm{m}$ intervals.

Dual immunostaining for CBPs and GAD was performed in series from four brains (CT80, CT81, CT82, and CT83). For Parv or Calb with GAD, series of sections were incubated overnight at room temperature with the mouse anti-Parv $(1: 1,000)$ or mouse anti-Calb (1:200) antibodies in conjunction with a rabbit polyclonal antibody for GAD67 (1:3,000; Chemicon International). The sections were subsequently incubated for 2 hours with a Cy2conjugated anti-mouse antiserum (1:200) for revelation of the Parv or Calb and with a Cy3-conjugated anti-rabbit antiserum $(1: 1,000)$ for revelation of the GAD enzyme (both secondary antibodies were from goat and supplied by Jackson Immuno Research). Similarly, the dual immunostaining of Calret with GAD was performed by incubating sections overnight in the rabbit anti-Calret antiserum $(1: 10,000)$ with a sheep anti-GAD antiserum $(1: 1,000$; supplied by E. Mugnaini, Chicago, IL; Oertel et al., 1982). These sections were then incubated with Cy2-conjugated anti-rabbit antiserum (1:50) for revelation of the Calret and a Cy3-conjugated anti-sheep antiserum (1:1,000) for revelation of the GAD enzyme (both secondaries from donkey; Jackson Immuno Research).

Dual immunostaining for CBPs with PAG (in series from CT80, CT81, CT82, CT83, PP1, and PP2) was performed by incubating adjacent series of sections with antibodies to the respective CBPs in conjunction with a rabbit anti-PAG antiserum (1:6,000, developed and kindly supplied by T. Kaneko, Kyoto, Japan; Akiyama et al., 1990). The sections were incubated in the mouse anti-Parv antibody $(1: 1,000)$ with the rabbit anti-PAG antibody (1: $6,000)$ and subsequently in a biotinylated anti-mouse secondary antibody $(1: 1,000)$ followed by Cy2-conjugated streptavidin (1:1,000) for Parv with a Cy3-conjugated anti-rabbit antiserum $(1: 1,000)$ for PAG (both secondary antibodies were from donkey and supplied by Jackson Immuno Research). In another series, sections were incubated with the mouse anti-Calb antibody (1:200) with the rabbit anti-PAG antibody, followed by a Cy2-conjugated anti-mouse antiserum (1:200) for revelation of Calb and a Cy3-conjugated anti-rabbit antiserum (1:1,000) for revelation of PAG (both secondary antibodies were from goat; Jackson Immuno Research). Dual immunostaining of Calret with PAG was performed by incubating an adjacent series of sections with a goat polyclonal antibody for Calret (1:2,500; Chemicon International) and rabbit anti-PAG $(1: 6,000)$. The sections were subsequently incubated with biotinylated anti-goat antiserum (1:50) followed by a Cy2conjugated streptavidin (1:1,000) for revelation of Calret and a Cy3-conjugated anti-rabbit antiserum (1:1,000) for revelation of PAG (with both secondaries from donkey; Jackson Immuno Research).

Dual immunostaining for Calb with ChAT was performed in two brains (CT81 and CT82) by incubating sections with the mouse anti-Calb antiserum (1:200) and a rabbit anti-ChAT antiserum (1:3,000; Chemicon International). The sections were subsequently incubated with Cy2-conjugated anti-mouse antiserum (1:200) for revelation of Calb and a Cy3-conjugated anti-rabbit antiserum $(1: 1,000)$ for revelation of the ChAT enzyme (both secondaries were from goat; Jackson Immuno Research).

For all series of immunofluorescent staining, the primary and secondary antibodies were diluted in TS $(0.1 \mathrm{M}$, $\mathrm{pH} 7.4$ ) that contained $1 \%$ bovine serum albumin and was also used for rinses between incubations. Before incubation with the primary antibody, the sections were placed in TS with $6 \%$ bovine serum albumin for blocking. Controls were routinely run with every dual-immunostaining procedure by omitting the primary antibodies and for antisera, replacing them with normal sera from the same species. At the end of processing, all sections were washed in TS, mounted from TS, dehydrated, and coverslipped with Permount (Fisher Scientific).

\section{Analysis}

Immunoperoxidase material. For the analysis of immunoperoxidase-stained material (performed by I.G.), a computer-based two-dimensional image analysis system (Biocom, Les Ulis, France) was employed. It comprised a Leitz Orthoplan microscope equipped with an $\mathrm{x}-/ \mathrm{y}-$ sensitive stage and video camera connected to a Compaq 386 computer. For assessment of CT injection sites, the region of the deposit in the cortex was outlined, and the retrogradely labeled neurons were mapped in the cortex and thalamus. For morphologic and numerical assessments of CBP-immunopositive $(+)$ and $\mathrm{CT}^{+}$cells in the $\mathrm{BF}$, cells were drawn or plotted through the basal forebrain cholinergic cell area. For this purpose, a previously designed and published computer atlas (Gritti et al., 1993) was used that allowed fitting of each section to the atlas and plotting of cells into the contours of the cytoarchitectonically and immunohistochemically delineated nuclei of the BF at six levels (separated by $800 \mu \mathrm{m}$ ) from $\sim \mathrm{A} 10.9$ to $\sim$ A6.9 (with reference to Paxinos and Watson, 1986). For mapping, all profiles of nerve cell bodies that were immunopositive were plotted (by using a $40 \times$ objective) through the entire area of each nucleus at each level (Gritti et al., 1993). For measurement of cell soma length, nerve cell bodies were selected at relatively equally spaced intervals through the full area of each nucleus and drawn in contour by using a $40 \times$ objective. In those series dual immunostained for CBPs and CT, cells were drawn or plotted as CBP/CT immunopositive or immunonegative to compute averages or totals for the CBP and CT cell groups. Accordingly, cells were classified as: $\mathrm{Parv}^{+} / \mathrm{CT}^{+}, \mathrm{Calb}^{+} / \mathrm{CT}^{+}$, or Calret $^{+} / \mathrm{CT}^{+}$; $\mathrm{Parv}^{+} / \mathrm{CT}^{-}, \mathrm{Calb}^{+} / \mathrm{CT}^{-}$, or $\mathrm{Calret}^{+} / \mathrm{CT}^{-}$; or $\mathrm{Parv}^{-} / \mathrm{CT}^{+}, \mathrm{Calb}^{-} / \mathrm{CT}^{+}$, or Calret ${ }^{-} / \mathrm{CT}^{+}$.

Total cell counts were computed per nucleus in one brain for single-labeled CBP cell types and in multiple brains (three or four) for double-labeled CBP/CT cell types. The estimated total numbers of cells were calculated according to Abercrombie's (1946) formula by multi- 
plication of the raw cell counts by the number of sections per interval and by a correction factor for cell size (mean large diameter) in relation to section thickness, i.e., section thickness $(\mu \mathrm{m}) /($ section thickness $[\mu \mathrm{m}]+$ cell diameter $[\mu \mathrm{m}])$, calculated per nucleus in the same manner performed previously for estimation of $\mathrm{GAD}^{+}$and $\mathrm{ChAT}^{+}$ cell numbers (Gritti et al., 1993, 1994, 1997).

Immunofluorescent material. For assessment of dual-immunostaining for CBP and the EPs, GAD, PAG, or ChAT, series of sections were examined (by I.D.M.) under fluorescent illumination for double labeling of the CBP cells with the EP. The sections were examined with a Leitz Dialux EB20 microscope equipped with a Ploemopak 2 reflected light fluorescence illuminator and Leica filter cubes for fluorescein (I3 with excitation between 450 and $490 \mathrm{~nm}$ and long pass emission above $515 \mathrm{~nm}$ ) and rhodamine (N2.1 with excitation between 515 and $560 \mathrm{~nm}$ and long pass above $590 \mathrm{~nm}$ ). Because the fluorescent images could not be transmitted by video camera and mapped with our image analysis system (as for the immunoperoxidase material), fluorescent cells were examined under the microscope by using a $63 \times$ oil objective and their single or dual immunostaining was tabulated by hand. In each microscopic field, all $\mathrm{CBP}^{+}$cell body profiles were evaluated for double labeling with the respective $\operatorname{EPs}\left(\mathrm{EP}^{+}\right)$. Because of fewer labeled cells due to lower sensitivity in immunofluorescence than in immunoperoxidase material, cells were examined on all sections of each series. By progressing systematically through the nuclei (except the olfactory tubercle) of the $\mathrm{BF}, \mathrm{CBP}^{+}$cell body profiles were accordingly judged as $\mathrm{EP}^{+}$or $\mathrm{EP}^{-}$and tabulated per microscopic field starting at $\sim \mathrm{A} 10.9$ and moving caudally to $\sim \mathrm{A} 6.9$ at $400-\mu \mathrm{m}$ intervals through the BF nuclei (to yield $\sim 60-160$ profiles sampled for the different series across nuclei). Three series were examined for the CBPs dual immunostained with GAD or PAG, and two series were examined for Calb with ChAT. Results were tabulated for calculation and presentation of the average proportion of the respective $\mathrm{CBP}^{+}$cells examined that were $\mathrm{GAD}^{+}, \mathrm{PAG}^{+}$, or $\mathrm{ChAT}^{+}$.

Statistical analysis was performed with Systat 9.0 (SPSS, Chicago, IL). Color photographs were prepared with Adobe Photoshop 5.0 (Adobe Systems, San Jose, CA). Atlas diagrams (from Biocom) were prepared as composite illustrations with Corel Draw 8.0 (Ottawa, Canada).

\section{RESULTS}

\section{Distribution of CBP-containing neurons}

Through the cholinergic cell area of the BF, where cholinergic and GABAergic cells are codistributed, there were neurons containing the CBPs Parv, Calb, or Calret. The $\mathrm{CBP}^{+}$cells were of different sizes and shapes, from small to large and oval, fusiform, or polygonal (Fig. 1A,C,E). The Parv $^{+}$BF cells often were multipolar in shape and appeared to be commonly and relatively large in size (Fig. 1A; with a maximum large diameter of $29.6 \mu \mathrm{m}$ and mean \pm standard deviation of $16.9 \pm 3.7 \mu \mathrm{m}$; Table 1 ). $\mathrm{Calb}^{+} \mathrm{BF}$ cells were highly variable in shape and size but, in addition to many small cells, included relatively large multipolar cells (Fig. 1C; with a maximum large diameter of $27.7 \mu \mathrm{m}$ and $14.8 \pm 3.6 \mu \mathrm{m}$; Table 1). The Calret ${ }^{+} \mathrm{BF}$ cells also were variable, often oval or fusiform and bipolar (Fig. 1E) and, in addition to many small or medium cells, included some large cells (with a maximum large diameter of $25.8 \mu \mathrm{m}$ and $15.5 \pm 3.7 \mu \mathrm{m}$; Table 1 ).

Through the $\mathrm{BF}$, the $\mathrm{CBP}^{+}$cell groups were distributed throughout the cholinergic cell nuclei (Figs. 2, 3, 4), where they appeared to be more numerous than $\mathrm{GAD}^{+}$cells (Gritti et al., 1993). According to estimates of total numbers of cells in one brain (Table 1$), \mathrm{Parv}^{+}(\sim 23,000), \mathrm{Calb}^{+}$ $(\sim 72,000)$, and Calret ${ }^{+}(\sim 27,000)$ cells greatly outnumbered $\mathrm{GAD}^{+}$and $\mathrm{ChAT}^{+}$cells in the BF nuclei (estimated at $\sim 39,000$ and $\sim 18,000$ according to similar calculations by Gritti et al., 1993). This also was the case with the exclusion of cells in the olfactory tubercle, where many small $\mathrm{Calb}^{+}$cells are located, for BF totals of 18,243 Parv $^{+}, 34,690 \mathrm{Calb}^{+}, 22,527$ Calret $^{+}, 30,791 \mathrm{GAD}^{+}$; and 15,056 $\mathrm{ChAT}^{+}$.

\section{Distribution of cortically projecting CBP-containing neurons}

To determine whether the different CBP-containing cell groups comprised cortically projecting neurons, retrograde labeling with $\mathrm{CT}$ was examined in $\mathrm{CBP}^{+}$neurons by dual immunostaining using immunoperoxidase in brains with CT injections into the prefrontal or parietal cortex.

CT injection sites. The position and extent of the CT injections in the prefrontal and parietal cortices were assessed by the CT deposit in the cortex (Fig. 5) and then by the distribution of retrogradely labeled projection neurons in the contralateral cortex and in the ipsilateral thalamus within each brain, as previously documented (Gritti et al., 1997).

Injections were centered in the medial prefrontal cortex in four rats. The CT deposit was commonly located in the medial/ventral orbital cortex (MO/VO) and extended into the prelimbic cingulate cortex, area $3(\mathrm{Cg} 3)$, more dorsally (Fig. 5A), similarly to previously published prefrontal cortex injection sites (Gritti et al., 1997). Across rats the injection sites also overlapped to varying degrees into the ventrolateral orbital (VLO) cortex laterally (CT25 and CT26), the infralimbic (IL) cortex caudally (CT25 and CT26) and the prelimbic cingulate cortex, area $1(\mathrm{Cg} 1)$, cortex dorsally (CT27). Retrogradely labeled corticocortical projection neurons were located in the contralateral homotypic cortex, including MO/VO (CT22, CT25, CT26, and CT27), VLO (CT25 and CT26), Cg3 (CT22, CT25, CT26, and CT27), IL (CT25 and CT26), and Cg1 (CT27). Retrogradely labeled thalamocortical projection neurons were commonly located in the mediodorsal nucleus (MD), the centrolateral nucleus (CL), and the midline, reuniens $(\mathrm{Re})$, and rhomboid ( $\mathrm{Rh}$ ) nuclei. A few retrogradely labeled neurons were also observed in different animals in the paratenial (PT), paraventricular (PV), centromedial (CM), paracentral (PC), anteromedial (AM), interanteromedial (IAM), intermediodorsal (IMD), and ventromedial (VM) nuclei.

Injections were centered in the parietal cortex in four rats. The CT deposit was located over the primary somatosensory cortex, parietal cortex 1 (Par1, Fig. 5B), similarly to previously published parietal cortical injection sites (Gritti et al., 1997). All injections (CT24, CT29, CT30, and CT31) were centered in the dorsomedial region of Par1. The retrogradely labeled corticocortical projection neurons were located predominantly in the contralateral homotypic Par1 cortex. In all rats, the retrogradely labeled thalamocortical neurons were located predominantly in the ventroposterior lateral and medial nuclei (VPL and 

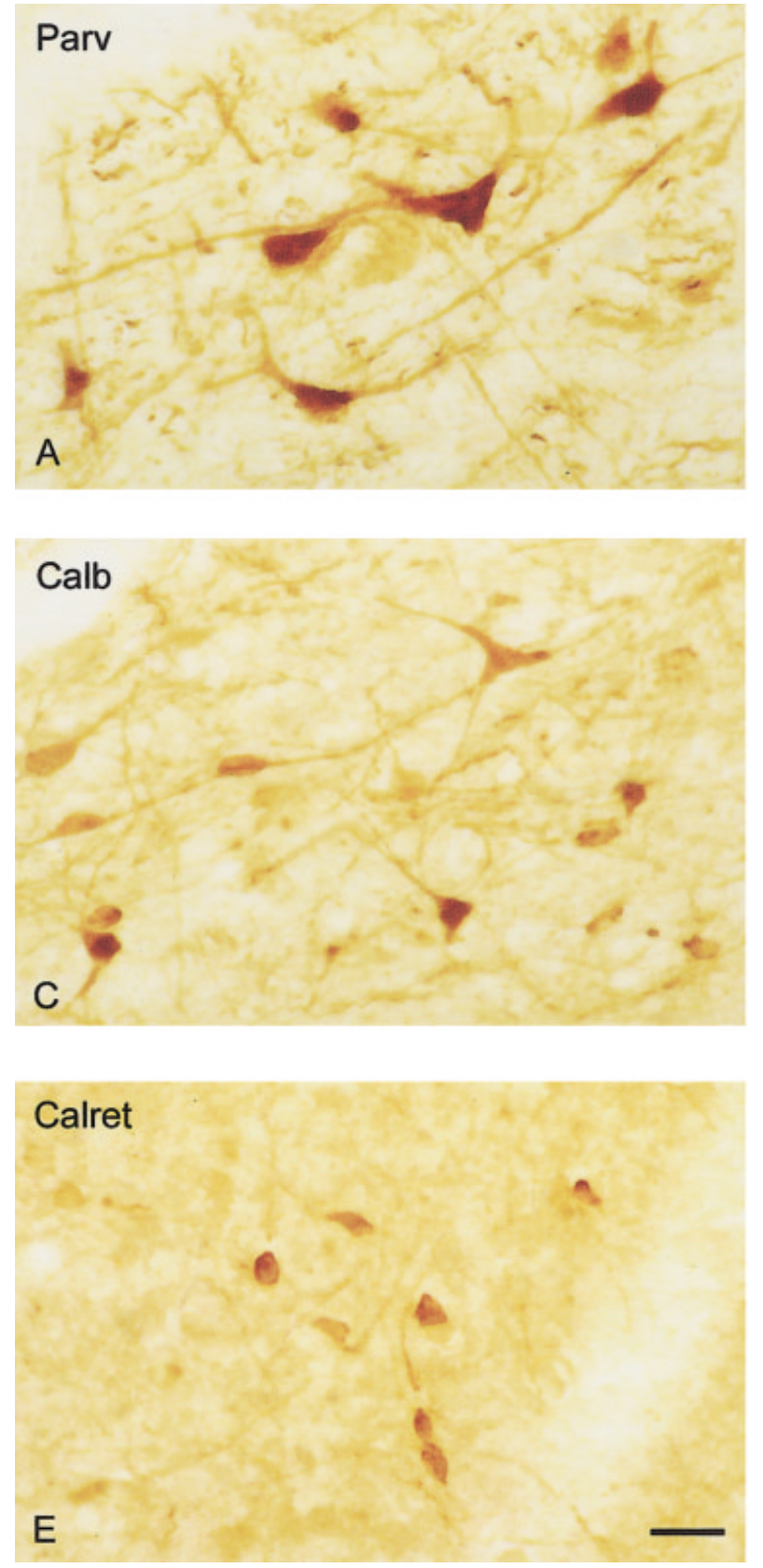

Fig. 1. Photomicrographs of sections taken through the basal forebrain (BF) cholinergic cell area and processed by immunoperoxidase staining for parvalbumin (Parv), calbindin (Calb), or calretinin (Calret) by single immunostaining $(\mathbf{A}, \mathbf{C}, \mathbf{E})$ or for Parv and cholera toxin (CT), Calb-CT, or Calret-CT by dual immunostaining $(\mathbf{B}, \mathbf{D}, \mathbf{F})$ by using 3, 3'-diaminobenzidine (DAB) for the calcium binding proteins $(\mathrm{CBPs})$ and $\mathrm{DAB}$ with nickel intensification for $\mathrm{CT}$. The retrograde

VPM) and in the posterior (PO), centromedial (CM), centrolateral (CL), and PC (paracentral) nuclei.

Retrogradely labeled $\mathrm{CBP}^{+}$neurons. Across the $\mathrm{BF}$ cholinergic cell area, $\mathrm{CBP}^{+}$cells were retrogradely labeled with CT from the prefrontal cortex and the parietal cortex (Fig. 1). Substantial numbers of $\mathrm{Parv}^{+} / \mathrm{CT}^{+}$cells were retrogradely labeled and often darkly labeled with many
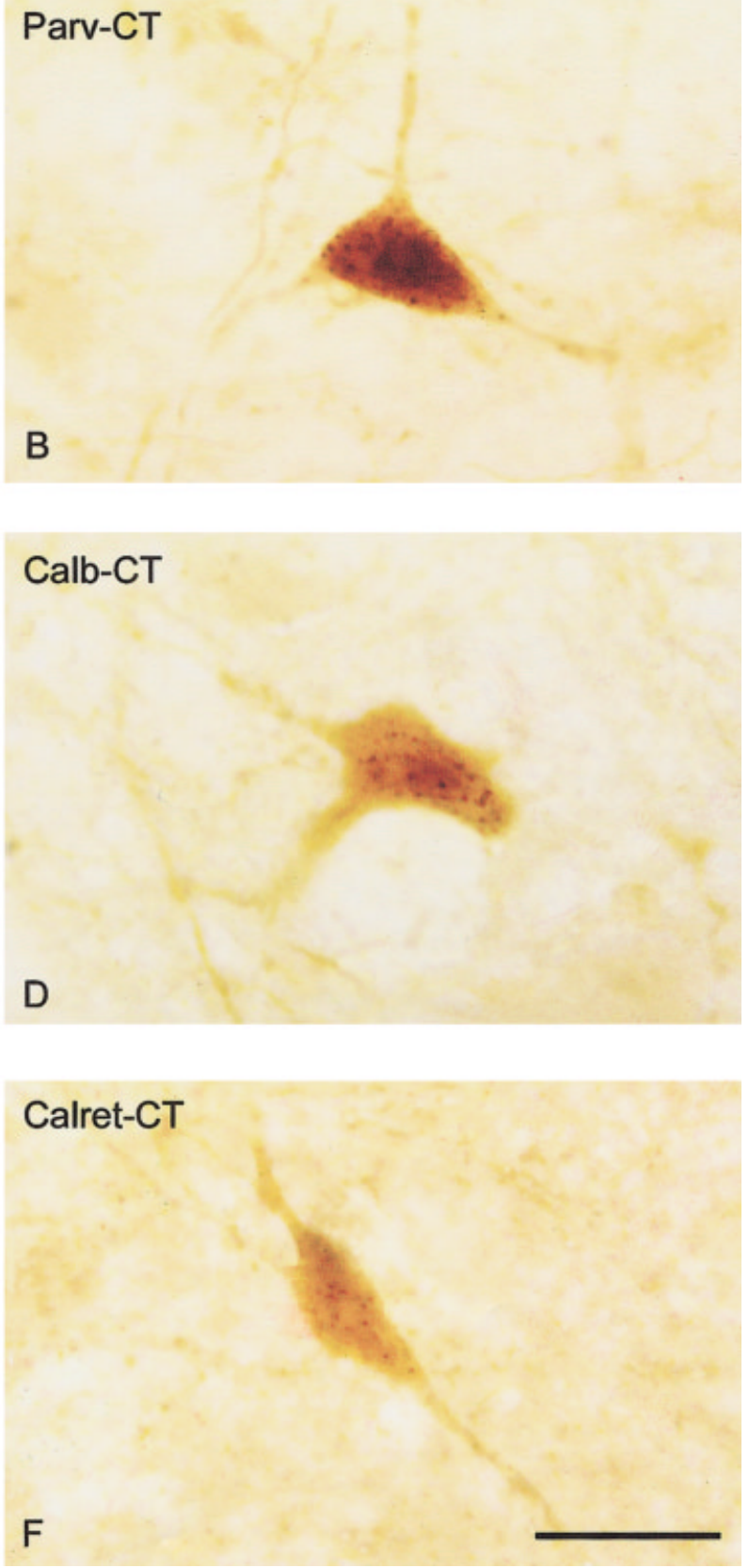

labeling is evident by the darkly stained $\mathrm{CT}^{+}$granules in the soma (B, $\mathrm{D}, \mathrm{F})$. Images are taken from the region of the magnocellular preoptic nucleus and substantia innominata pars anterior (near the perforating blood vessels seen in A, C, and E; near A8.5, Figs. 2-4) to show single- $(\mathrm{A}, \mathrm{C}, \mathrm{E})$ and dual- $(\mathrm{B}, \mathrm{D}, \mathrm{F})$ immunostained $\mathrm{CBP}^{+}$and $\mathrm{CBP}^{+} /$ $\mathrm{CT}^{+}$cells, respectively $\left(\mathrm{Parv}^{+}\right.$and $\mathrm{Parv}^{+} / \mathrm{CT}^{+}$cells; $\mathrm{Calb}^{+}$and $\mathrm{Calb}^{+} /$ $\mathrm{CT}^{+}$cells; and Calret ${ }^{+}$and Calret ${ }^{+} / \mathrm{CT}^{+}$cells). Scale bars $=20 \mu \mathrm{m}$.

prominent $\mathrm{CT}^{+}$granules in their soma (Fig. 1B). Similarly, many $\mathrm{Calb}^{+} / \mathrm{CT}^{+}$cells were retrogradely labeled and often darkly so, indicating many prominent $\mathrm{CT}^{+}$ granules (Fig. 1D). Very few Calret ${ }^{+}$cells could be found that were retrogradely labeled, and these were very lightly labeled, indicating small numbers of light $\mathrm{CT}^{+}$ granules (Fig. 1F). Given their rarity and minimal label- 


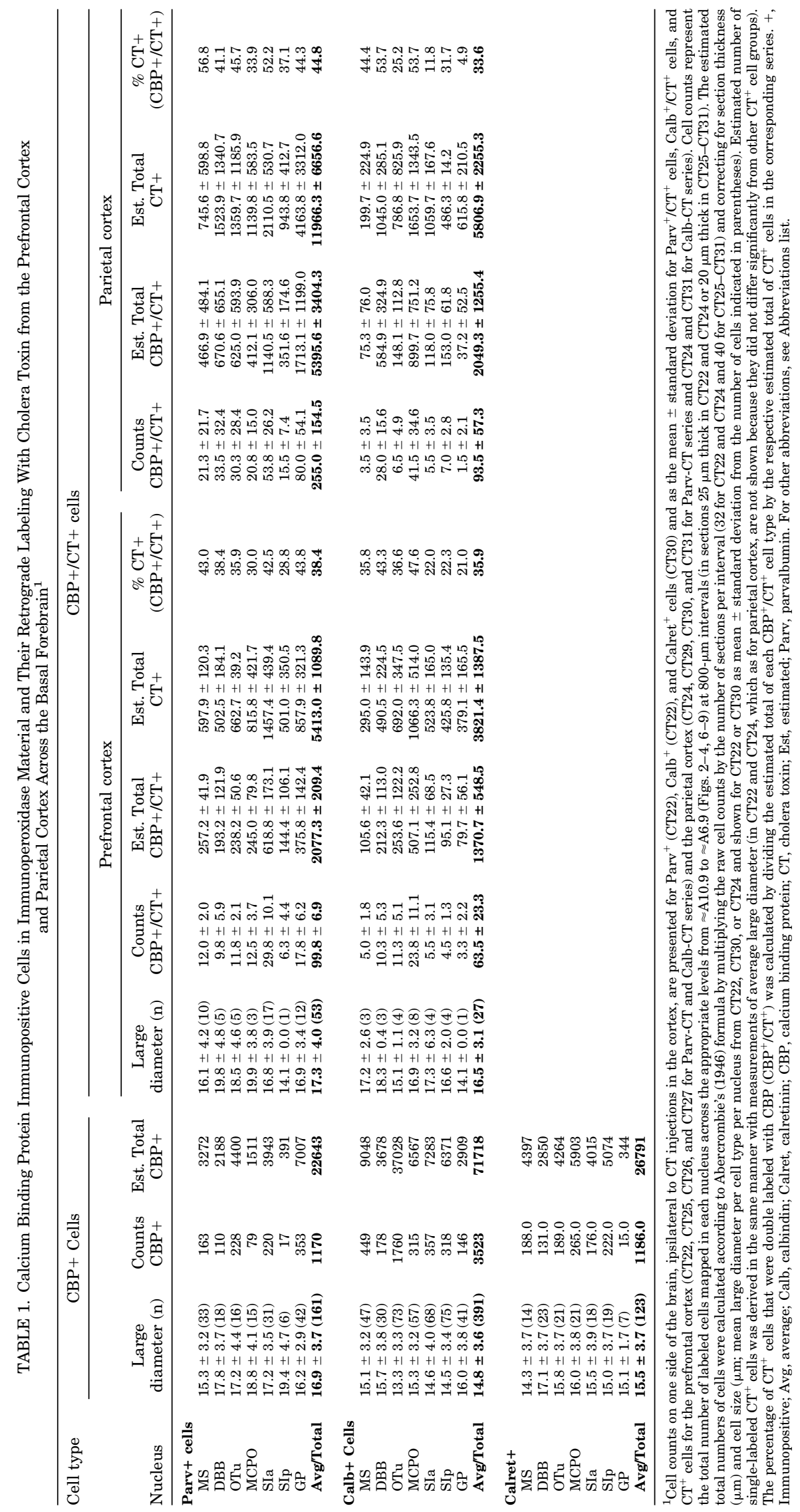




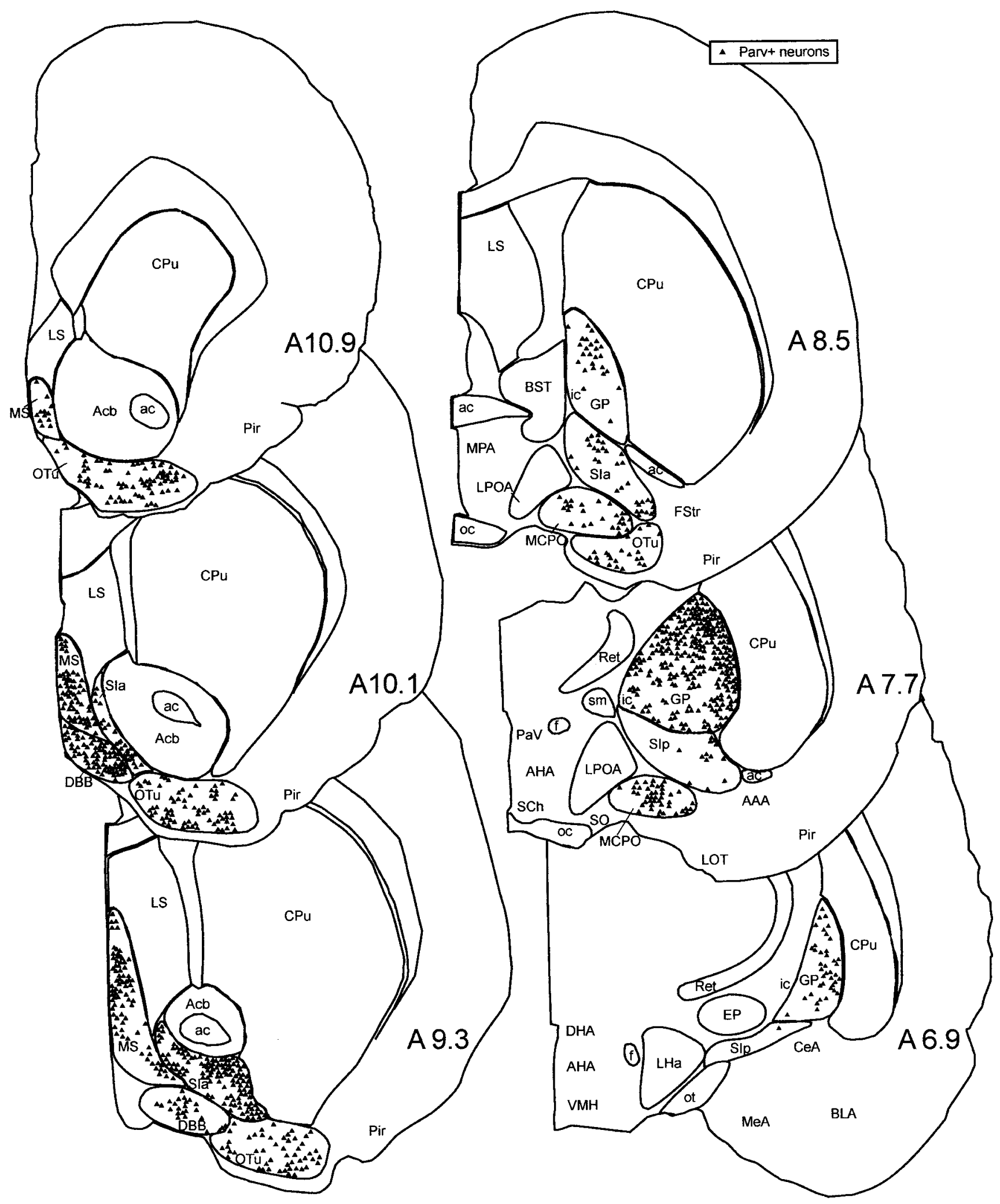

Fig. 2. Computer-based atlas figures of the basal forebrain cholinergic cell area (Gritti et al., 1993) in which parvalbumin-immunopositive neurons were plotted. Each symbol marks one labeled cell. For abbreviations, see Abbreviations list. 


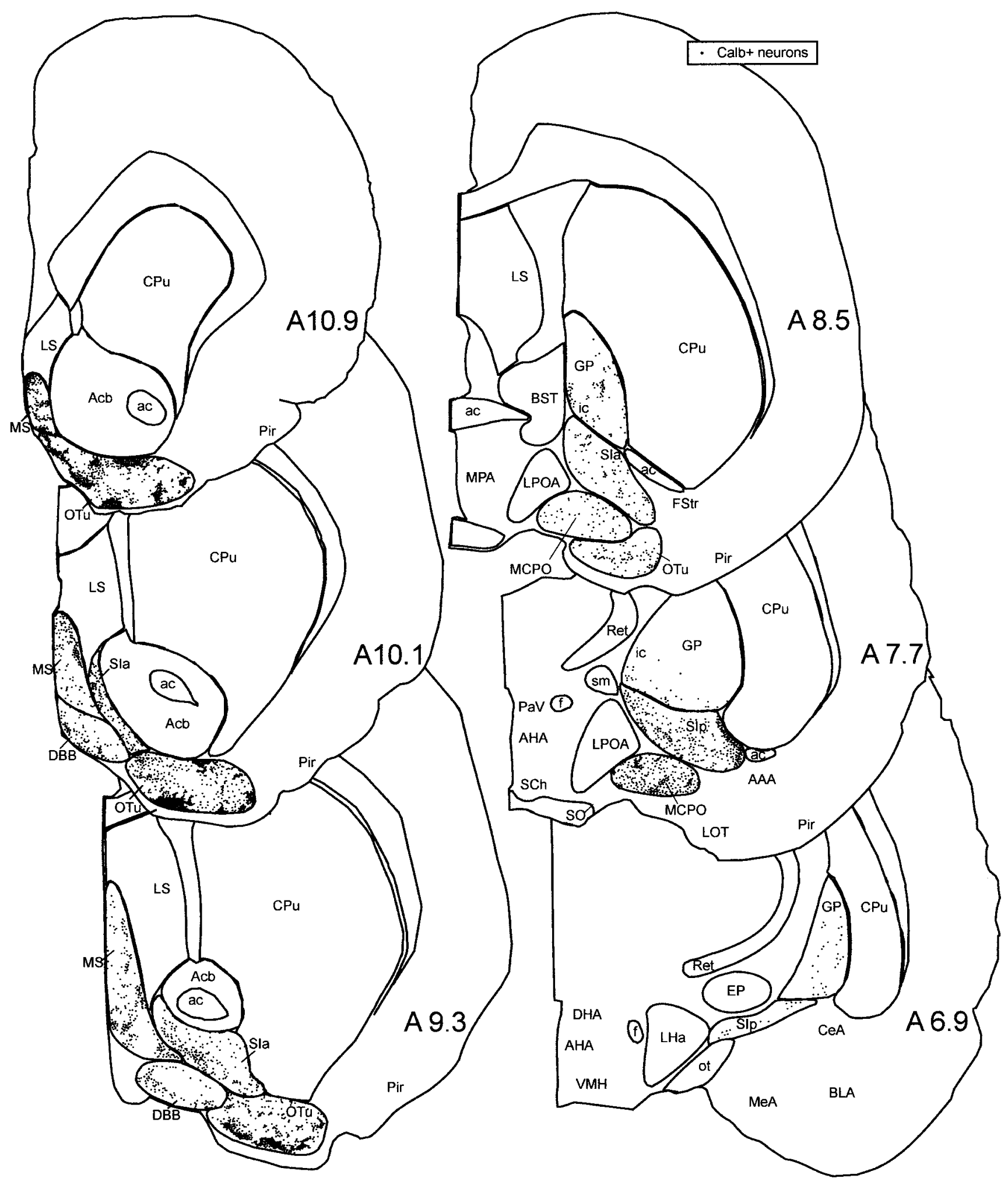

Fig. 3. Computer-based atlas figures of the basal forebrain cholinergic cell area in which calbindinimmunopositive neurons were plotted. Each symbol marks one labeled cell. For abbreviations, see Abbreviations list. 


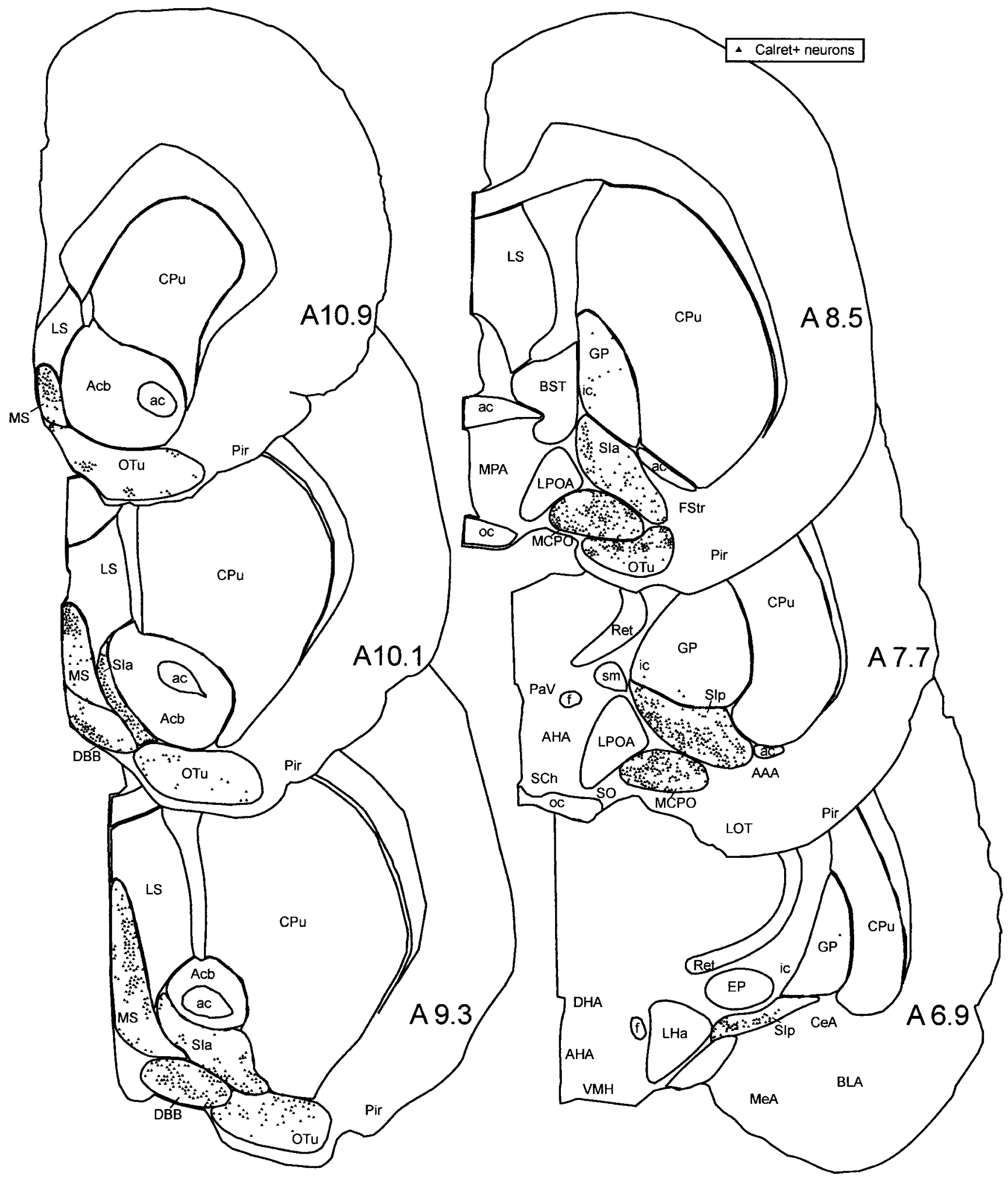

Fig. 4. Computer-based atlas figures of the basal forebrain cholinergic cell area in which calretininimmunopositive neurons were plotted. Each symbol marks one labeled cell. For abbreviations, see Abbreviations list. 


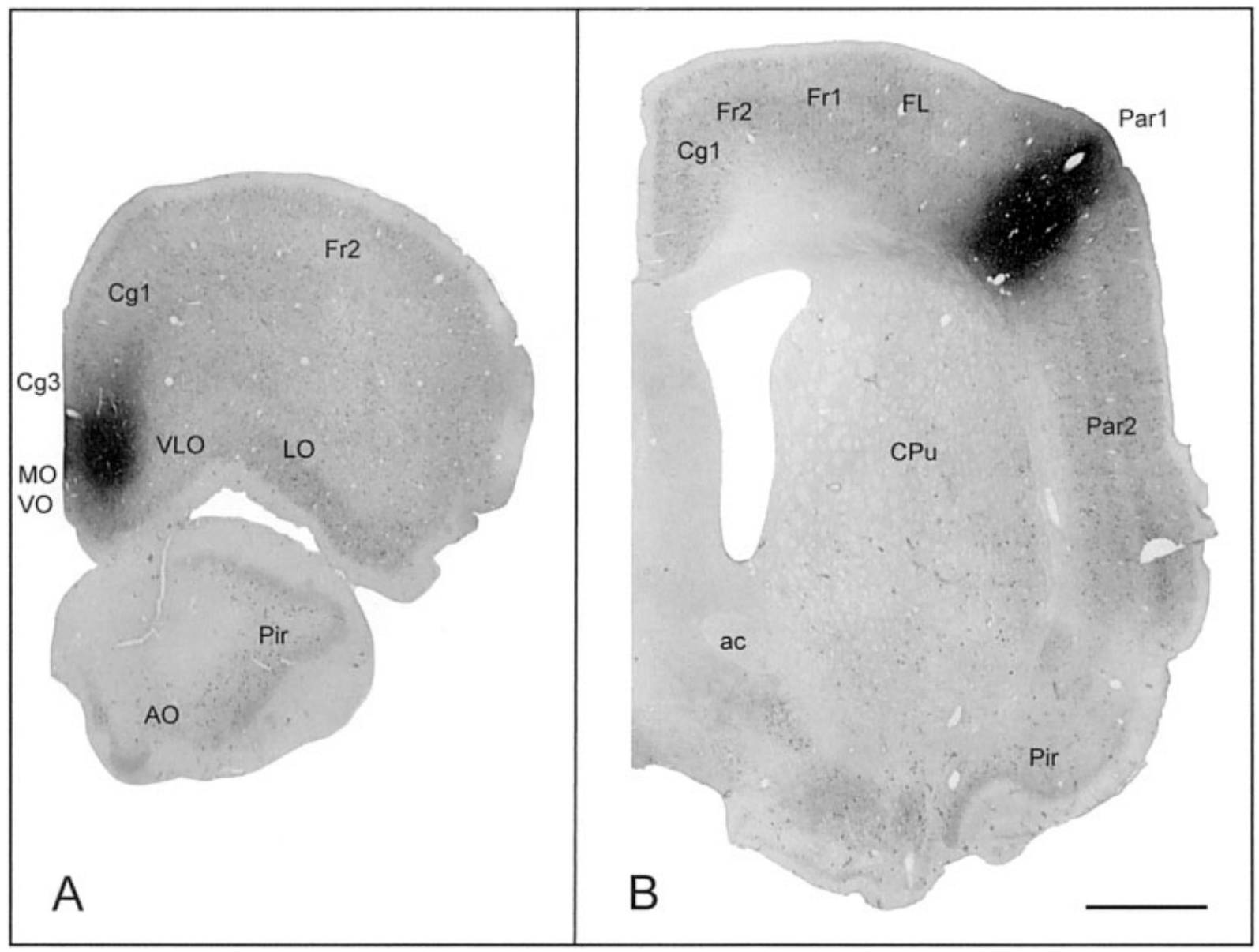

Fig. 5. Images of cholera toxin subunit $\mathrm{b}$ injection sites in the prefrontal cortex $(\mathbf{A} ; \sim$ A12.7) and parietal cortex $(\mathbf{B} ; \sim$ A9.7) taken from representative cases. The injection in the prefrontal cortex in cluded the medial-ventral orbital cortex (MO/VO) and area 3 of the cingulate cortex (Cg3). In the parietal cortex, the injection was situated in the dorsomedial region of area 1 (Par1) of the somatosensory cortex. For other abbreviations, see Abbreviations list. Scale bar $=1$ $\mathrm{mm}$. ing, the Calret ${ }^{+} / \mathrm{CT}^{+}$cells were not considered to represent a significant group of cortically projecting cells and thus were not systematically studied. Clearly representing significant numbers of retrogradely labeled cells, all $\mathrm{Parv}^{+} / \mathrm{CT}^{+}$and $\mathrm{Calb}^{+} / \mathrm{CT}^{+}$cells were mapped and tabulated in multiple brains with $\mathrm{CT}$ injections in the prefrontal or parietal cortex.

In the $\mathrm{BF}, \mathrm{Parv}^{+}$and $\mathrm{Calb}^{+}$cells, which were retrogradely labeled from the prefrontal cortex or the parietal cortex, appeared similar in size. As for the total group of $\mathrm{Parv}^{+}$cells, the $\mathrm{Parv}^{+} / \mathrm{CT}^{+}$cells were often polygonal and relatively large (Fig. 1B; with average large diameter of $17.3 \pm 4.0 \mu \mathrm{m}$ from prefrontal cortex; Table 1$) . \mathrm{Calb}^{+} / \mathrm{CT}^{+}$ cells also were often polygonal and relatively large (Fig. $1 \mathrm{D}$; with average large diameter of $16.5 \pm 3.1 \mu \mathrm{m}$ from prefrontal cortex; Table 1). These cortically projecting $\mathrm{CBP}^{+}$cells did not appear to differ significantly in shape or size from cortically projecting $\mathrm{GAD}^{+}$or $\mathrm{ChAT}^{+}$cells according to measurements in our previous studies (with mean large diameters of $17.7 \pm 3.9 \mu \mathrm{m}$ and $19.1 \pm 3.9 \mu \mathrm{m}$, respectively; Gritti et al., 1997). The $\mathrm{BF} \mathrm{CBP}^{+} / \mathrm{CT}^{+}$cells retrogradely labeled from the prefrontal (Figs. 6, 7) or parietal (Figs. 8, 9) cortex were intermingled with $\mathrm{CBP}^{-} /$
$\mathrm{CT}^{+}$cells and collectively distributed throughout the BF in a manner similar to previously published maps of basal cortical projection neurons (Gritti et al., 1997). With $\mathrm{CBP}^{-} / \mathrm{CT}^{+}$cells, the $\mathrm{Parv}^{+} / \mathrm{CT}^{+}$and $\mathrm{Calb}^{+} / \mathrm{CT}^{+}$cells comprised neurons that were lightly labeled (with $\sim 5$ to 10-15 $\mathrm{CT}^{+}$grains) in addition to those that were darkly labeled (with $\sim 10-15 \mathrm{CT}^{+}$, often prominent, grains; Figs. 6-9), which were tabulated together. The variation in the degree of retrograde labeling from dark to light was interpreted, as in our previous study, as reflecting the different densities of terminal innervation in the cortical target area by individual cells. Within the broader, overlapping distributions of retrogradely labeled neurons, darkly retrogradely labeled neurons from prefrontal as opposed to parietal cortex were clustered in different subregions of the BF, as previously noted (Gritti et al., 1997).

From the prefrontal and parietal cortexes, numerous $\mathrm{BF}$ $\mathrm{Parv}^{+} / \mathrm{CT}^{+}, \mathrm{Calb}^{+} / \mathrm{CT}^{+}$as well as $\mathrm{Parv}^{-} / \mathrm{CT}^{+}$and $\mathrm{Calb}^{-} /$ $\mathrm{CT}^{+}$neurons were retrogradely labeled (Figs. 6-9). The total number of retrogradely labeled cells and their apportionment across nuclei differed slightly across animals as a function of the variation in injection site placement. In addition, however, more retrogradely labeled cells were 


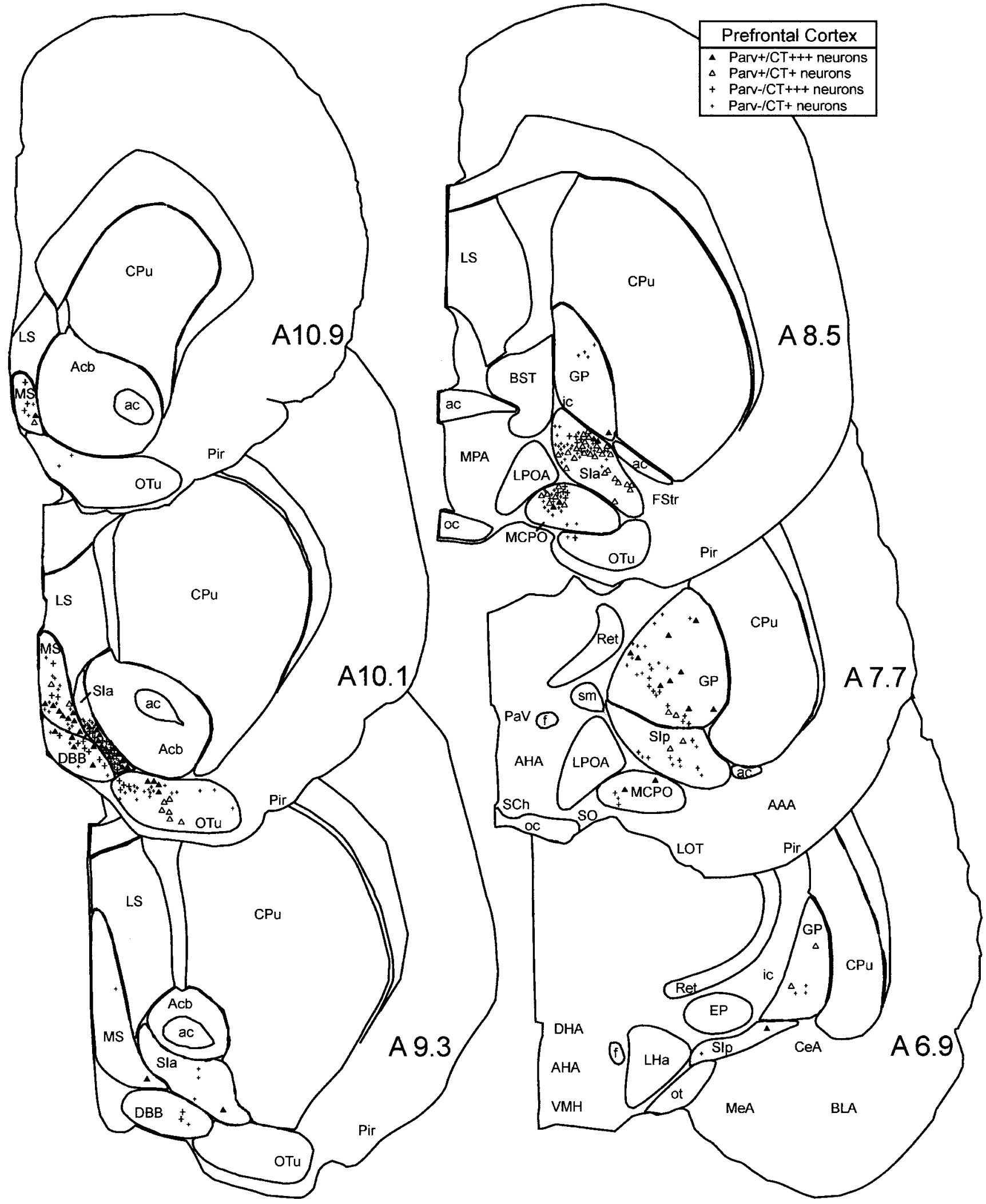

Fig. 6. Computer-based atlas figures of the basal forebrain (BF) cholinergic cell area on which parvalbumin-immunopositive $\left(\mathrm{Parv}^{+}\right)$ and other neurons that were retrogradely labeled with cholera toxin subunit $\mathrm{b}\left(\mathrm{CT}^{+}\right)$from the prefrontal cortex were mapped in a representative case. $\mathrm{Parv}^{+} / \mathrm{CT}^{+}$neurons (triangles) and $\mathrm{Parv}^{-} / \mathrm{CT}^{+}$neu- rons (crosses) are codistributed throughout the BF. Darkly retrogradely labeled cells $\left(\mathrm{CT}^{+++}\right.$, solid symbols and thick crosses) are distinguished from lightly retrogradely labeled cells $\mathrm{CT}^{+}$, open symbols and thin crosses). Each symbol marks one labeled cell. For abbreviations, see Abbreviations list. 


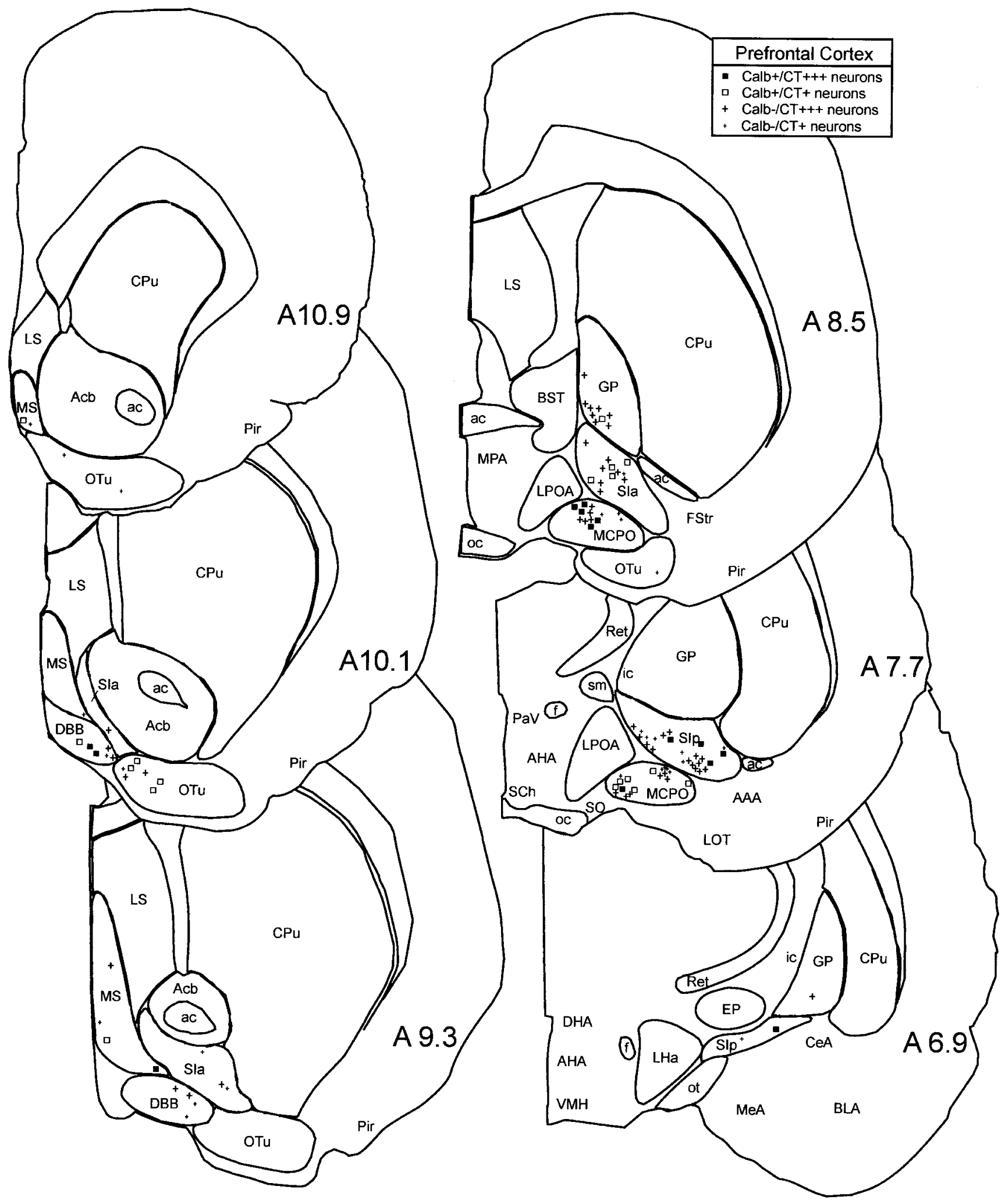

Fig. 7. Computer-based atlas figures of the basal forebrain (BF) cholinergic cell area on which calbindin-immunopositive $\left(\mathrm{Calb}^{+}\right)$and other neurons that were retrogradely labeled with cholera toxin subunit $\mathrm{b}\left(\mathrm{CT}^{+}\right)$from the prefrontal cortex were mapped in a representative case. $\mathrm{Calb}^{+} / \mathrm{CT}^{+}$neurons (squares) and $\mathrm{Calb}^{-} / \mathrm{CT}^{+}$neurons (crosses) are codistributed throughout the BF. Darkly retrogradely labeled cells $\left(\mathrm{CT}^{+++}\right.$, solid symbols and thick crosses) are distinguished from lightly retrogradely labeled cells $\left(\mathrm{CT}^{+}\right.$, open symbols and thin crosses). Each symbol marks one labeled cell. For abbreviations, see Abbreviations list. 


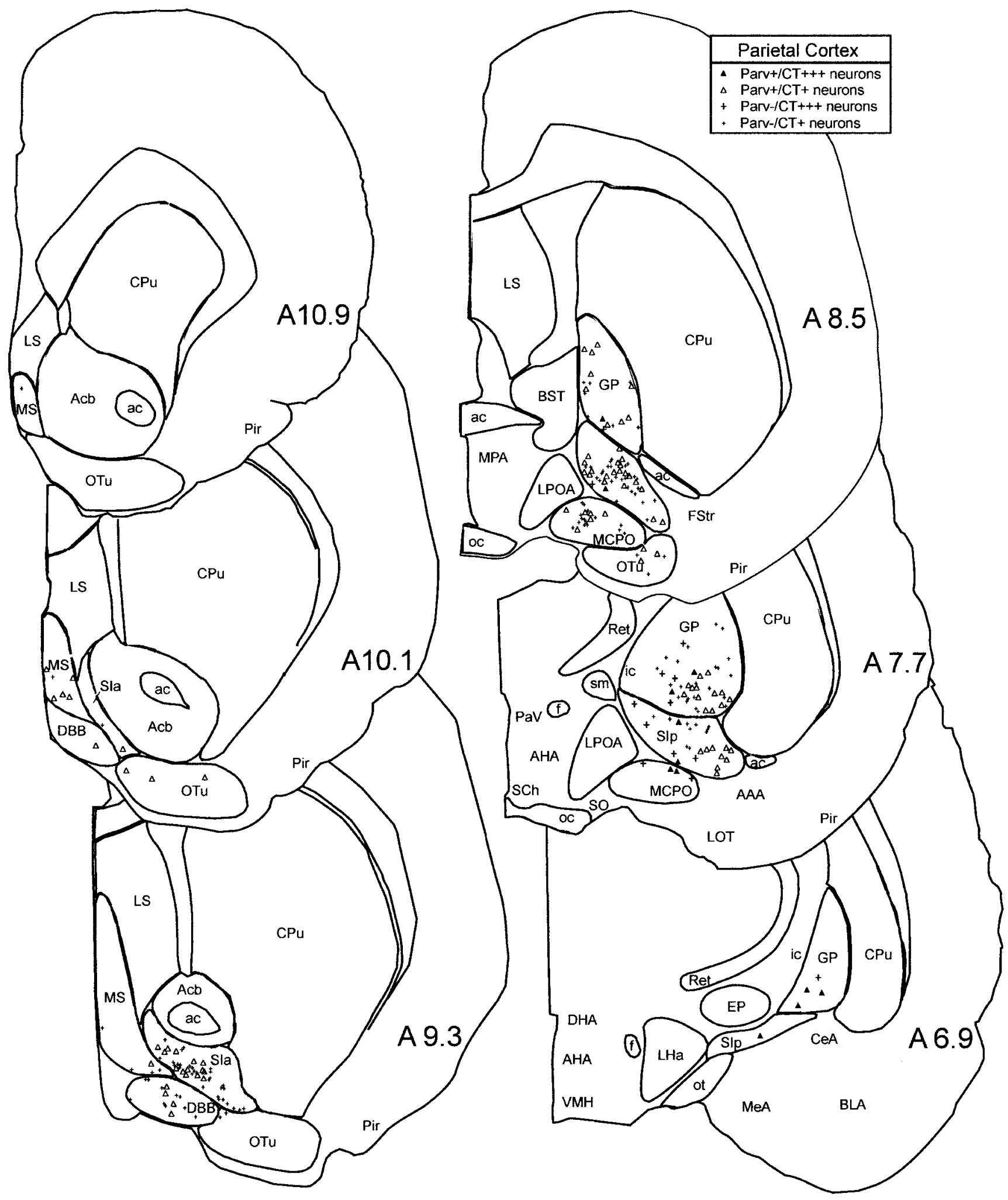

Fig. 8. Computer-based atlas figures of the basal forebrain (BF) cholinergic cell area on which parvalbumin-immunopositive $\left(\mathrm{Parv}^{+}\right)$ and other neurons that were retrogradely labeled with cholera toxin subunit $\mathrm{b}\left(\mathrm{CT}^{+}\right)$from the parietal cortex were mapped in a representative case. $\mathrm{Parv}^{+} / \mathrm{CT}^{+}$neurons (triangles) and $\mathrm{Parv}^{-} / \mathrm{CT}^{+}$neurons (crosses) are codistributed throughout the BF. Darkly retrogradely labeled cells $\left(\mathrm{CT}^{+++}\right.$, solid symbols and thick crosses) are distinguished from lightly retrogradely labeled cells $\left(\mathrm{CT}^{+}\right.$, open symbols and thin crosses). Each symbol marks one labeled cell. For abbreviations, see Abbreviations list. 


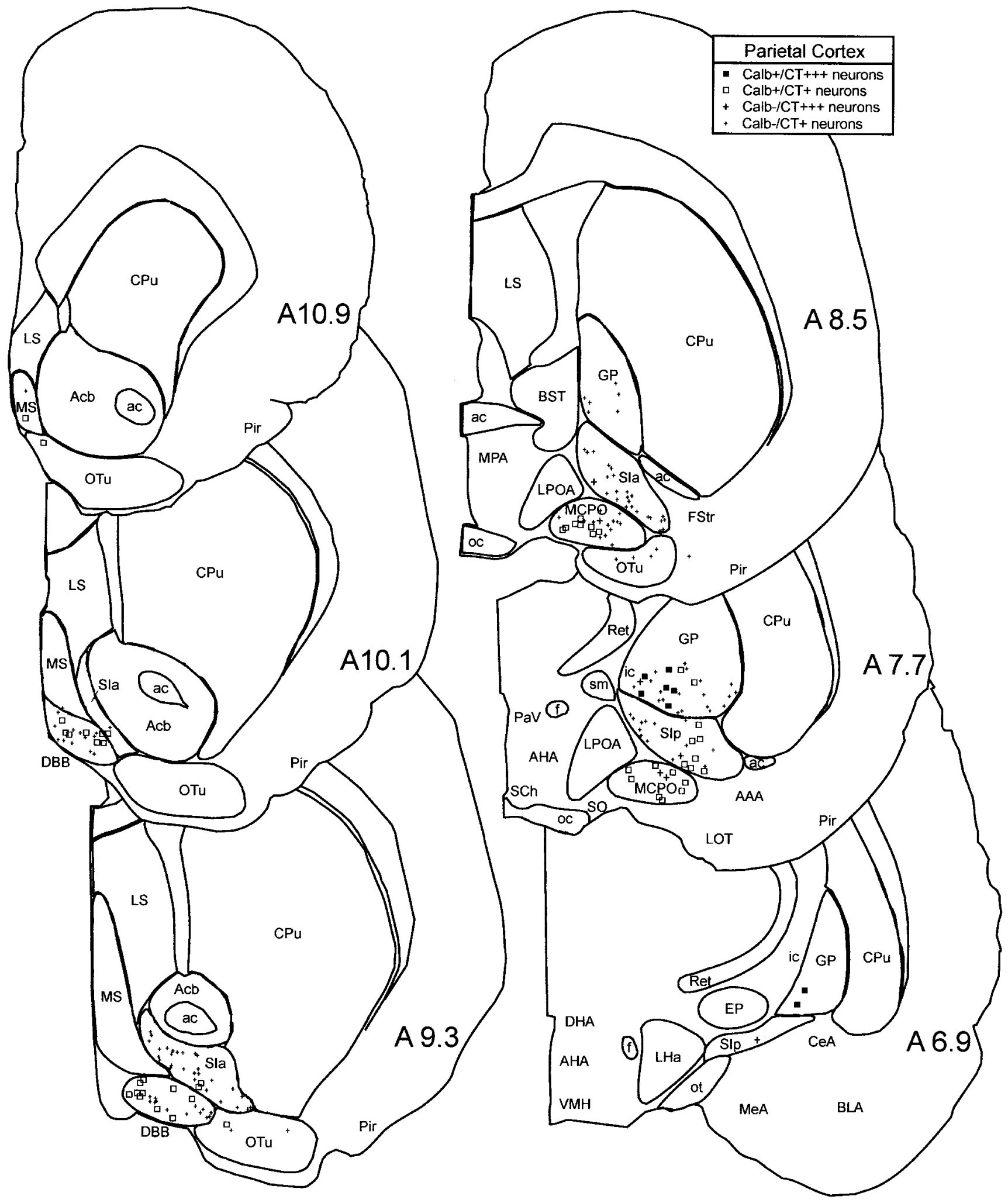

Fig. 9. Computer-based atlas figures of the basal forebrain (BF) cholinergic cell area on which calbindin-immunopositive $\left(\mathrm{Calb}^{+}\right)$and other neurons that were retrogradely labeled with cholera toxin subunit $b\left(\mathrm{CT}^{+}\right)$from the parietal cortex were mapped in a representative case. $\mathrm{Calb}^{+} / \mathrm{CT}^{+}$neurons (squares) and $\mathrm{Calb}^{-} / \mathrm{CT}^{+}$neurons (crosses) are codistributed throughout the BF. Darkly retrogradely labeled cells $\left(\mathrm{CT}^{+++}\right.$, solid symbols and thick crosses) are distinguished from lightly retrogradely labeled cells $\left(\mathrm{CT}^{+}\right.$, open symbols and thin crosses). Each symbol marks one labeled cell. For abbreviations, see Abbreviations list. 
TABLE 2. Calcium Binding Protein Immunopositive Neurons in Immunofluorescent Material That Were Dual Immunopositive for GAD or PAG in the Basal Forebrain ${ }^{1}$

\begin{tabular}{|c|c|c|c|c|c|c|}
\hline Cell type & $\mathrm{CBP}+$ & $\mathrm{CBP}+/ \mathrm{GAD}+$ & $\begin{array}{c}\% \mathrm{CBP}+ \\
(\mathrm{CBP}+/ \mathrm{GAD}+)\end{array}$ & $\mathrm{CBP}+$ & $\mathrm{CBP}+/ \mathrm{PAG}+$ & $\begin{array}{c}\% \mathrm{CBP}+ \\
(\mathrm{CBP}+/ \mathrm{PAG}+)\end{array}$ \\
\hline Parv+ & $98.7 \pm 3.8$ & $90.0 \pm 5.0$ & 91.2 & $58 \pm 1.7$ & $30.0 \pm 1.0$ & 51.7 \\
\hline Calb+ & $122.7 \pm 16.9$ & $5.3 \pm 0.6$ & 4.4 & $83.3 \pm 1.5$ & $37.3 \pm 3.5$ & 44.8 \\
\hline Calret+ & $158.8 \pm 14.4$ & $13.0 \pm 1.0$ & 8.2 & $110.0 \pm 3.6$ & $95.7 \pm 5.8$ & 86.9 \\
\hline
\end{tabular}

${ }^{1}$ The number of $\mathrm{CBP}^{+}$neurons (mean \pm standard deviation) examined across basal forebrain nuclei (except the olfactory tubercle) and the number of those that were double labeled for GAD $\left(\mathrm{CBP}^{+} / \mathrm{GAD}^{+}\right)$or PAG $\left(\mathrm{CBP}^{+} / \mathrm{PAG}^{+}\right)$are presented with the average percentage of each cell type that was double labeled (based on three dual-immunostained series per CBP from CT80, CT81, CT82, CT83, PP1 or PP2). +, Immunopositive; Calb, calbindin; Calret, calretinin; CBP, calcium binding protein; GAD, glutamic acid decarboxylase; PAG, phosphate activated glutaminase; Parv, parvalbumin.

detected in the Parv-CT than in the Calb-CT dualimmunostained series, possibly suggesting a different sensitivity in CT immunostaining depending on the antibodies used in the sequential dual immunostaining. Proportions of retrogradely labeled cells that were Parv ${ }^{+}$ or $\mathrm{Calb}^{+}$were calculated for individual series (Table 1). Similar relative proportions of these cell groups were found when considering only the darkly retrogradely labeled cells in the BF. From the prefrontal cortex, $\mathrm{Parv}^{+} /$ $\mathrm{CT}^{+}$neurons represented on average $\sim 38 \%$ and $\mathrm{Calb}^{+} /$ $\mathrm{CT}^{+}$neurons represented $\sim 36 \%$ of the cortically projecting cells. Taken together, $\mathrm{Parv}^{+} / \mathrm{CT}^{+}$and $\mathrm{Calb}^{+} /$ $\mathrm{CT}^{+}$cells did not account for $100 \%$ of $\mathrm{BF} \mathrm{CT}^{+}$cells that were retrogradely labeled from the prefrontal cortex (Table 1). From the parietal cortex, the average proportion of $\mathrm{Parv}^{+} / \mathrm{CT}^{+}$cells was $\sim 44 \%$ and that of the $\mathrm{Calb}^{+} / \mathrm{CT}^{+}$ cells was $\sim 34 \%$ (Table 1 ). Altogether, they did not account for $100 \%$ of $\mathrm{BF} \mathrm{CT}^{+}$cells that were retrogradely labeled from the parietal cortex (Table 1). For the prefrontal and parietal cortexes, the combined numbers and proportions of $\mathrm{Parv}^{+} / \mathrm{CT}^{+}$and $\mathrm{Calb}^{+} / \mathrm{CT}^{+}$cells greatly exceeded those previously estimated for $\mathrm{GAD}^{+} / \mathrm{CT}^{+}$cells, which represented $\sim 31-37 \%$ of $\mathrm{CT}^{+}$cells labeled from the same cortical areas (Gritti et al., 1997). They also somewhat exceeded the combined numbers and proportions of $\mathrm{GAD}^{+} /$ $\mathrm{CT}^{+}$and $\mathrm{ChAT}^{+} / \mathrm{CT}^{+}$cells, which represented $20-27 \%$ (Gritti et al., 1997).

\section{Colocalization of CBPs with GAD, ChAT, or PAG}

To determine whether the CBPs are colocalized with the synthetic enzymes for the neurotransmitters GABA, acetylcholine, or possibly glutamate in BF neurons, dual immunostaining was performed with immunohistofluorescence for the CBPs and EPs. Dual immunostaining was assessed in individual $\mathrm{CBP}^{+}$cells across the entire population through the BF nuclei, except cells in the olfactory tubercle (Table 2).

In sections dually immunostained for CBPs and GAD, a very large number $(>90 \%)$ of $\mathrm{Parv}^{+}$neurons was $\mathrm{GAD}^{+}$ (Fig. 10A,B; Table 2). In contrast, a very small number $(<5 \%)$ of $\mathrm{Calb}^{+}$neurons was GAD ${ }^{+}$(Fig. 10E,F; Table 2). Similarly, a very small number $(<10 \%)$ of Calret $^{+}$neurons was $\mathrm{GAD}^{+}$(Fig. 10I,J; Table 2).

In sections dually immunostained for Calb and ChAT, no $\mathrm{Calb}^{+}$neurons were $\mathrm{ChAT}^{+}$(not shown).

In sections dually immunostained for CBPs and the synthetic enzyme for the transmitter glutamate, PAG, a proportion $(\sim 50 \%)$ of $\mathrm{Parv}^{+}$cells was $\mathrm{PAG}^{+}$(Fig. 10C,D; Table 2). Slightly less than half $(\sim 45 \%)$ of $\mathrm{Calb}^{+}$neurons was $\mathrm{PAG}^{+}$(Fig. 10G,H; Table 2). Most Calret ${ }^{+}(>85 \%)$ neurons were $\mathrm{PAG}^{+}$(Fig. 10K,L; Table 2).

\section{DISCUSSION}

The present immunohistochemical results revealed that within the $\mathrm{BF}$ cholinergic cell area of the rat, neurons containing the CBPs Parv, Calb, and Calret are diverse in size and shape and distributed in a manner overlapping with the GABAergic neurons, but they are greater in number than the GABAergic cells therein. Parv ${ }^{+}$and $\mathrm{Calb}^{+}$neurons were retrogradely labeled from the cerebral cortex, like GABAergic and cholinergic neurons, but they were also larger in number than the GABAergic projection neurons. These results indicated that $\mathrm{CBP}^{+}$ neurons might comprise GABAergic and non-GABAergic neurons in the BF. Dual immunostaining for the CBPs and transmitter enzymes showed that, whereas the vast majority of $\mathrm{Parv}^{+}$neurons contains GAD, the vast majority of $\mathrm{Calb}^{+}$and $\mathrm{Calret}^{+}$neurons does not. They appeared to contain PAG in significant proportions, which is the enzyme for the synthesis of transmitter glutamate. Accordingly, caudally or locally projecting neurons would include Calret ${ }^{+}$, possibly glutamatergic, neurons, and the basal cortical projection neurons would be comprised principally of $\mathrm{Parv}^{+}$, likely GABAergic, neurons and $\mathrm{Calb}^{+}$, possibly glutamatergic, neurons in addition to $\mathrm{CBP}^{-}$cholinergic neurons.

\section{Methodologic considerations}

The initial aim of the present study was to determine whether subgroups of GABAergic neurons contain different CBPs that would allow their subsequent differentiation and identification. The findings in immunoperoxidase-stained material indicated that estimated numbers of CBPcontaining neurons greatly exceeded previously estimated numbers of $\mathrm{GAD}^{+}$cells. To permit this comparison, we plotted cell profiles with the aid of the same twodimensional image analysis system and estimated cell numbers with the same method (Abercrombie, 1946) used in our original work for estimating $\mathrm{GAD}^{+}$and $\mathrm{ChAT}^{+}$ cells in delineated nuclei of the BF (Gritti et al., 1993, 1994, 1997). Although such methods are increasingly being replaced by three-dimensional stereologic counting techniques (Coggeshall and Lekan, 1996), they nonetheless allow approximate estimates of cell numbers and are deemed appropriate when they are employed as in the present study for comparison with data obtained in the same manner (Guillery and Herrup, 1997). This comparison indicated that the combined numbers of the $\mathrm{CBP}^{+}$ cell groups greatly exceeded the number of $\mathrm{GAD}^{+}$cells and that the combined proportions of cortically projecting $\mathrm{CBP}^{+}$cell groups greatly exceeded that of the cortically projecting $\mathrm{GAD}^{+}$cells. Given these results, we examined in dual-immunofluorescent stained material whether 

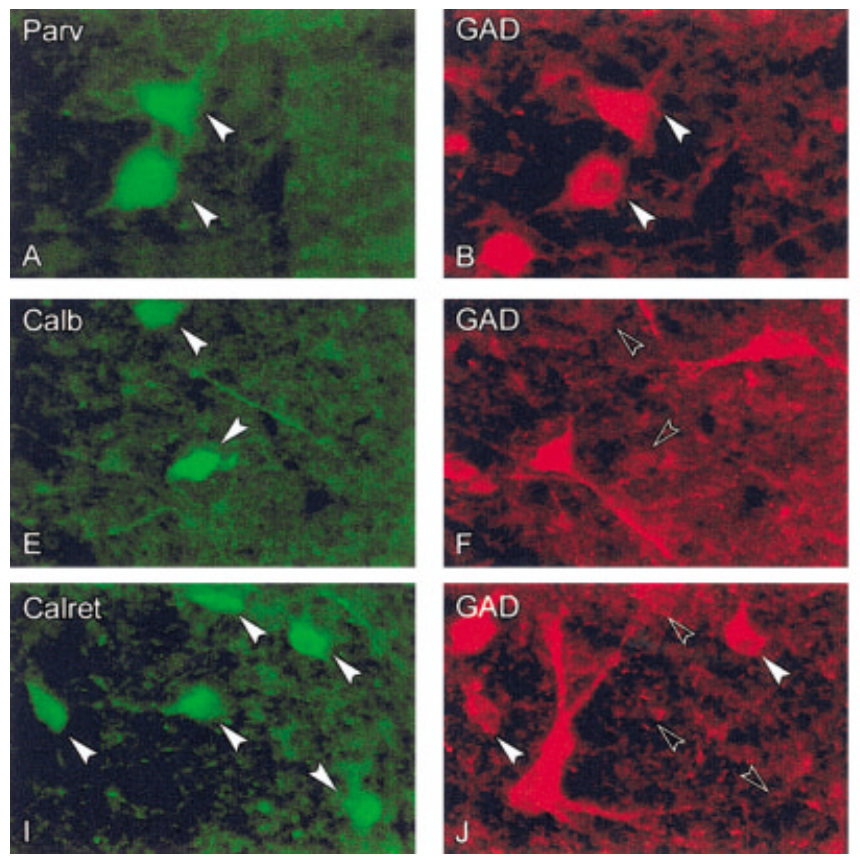

Fig. 10. Photomicrographs of sections through the basal forebrain (magnocellular preoptic nucleus) showing dual-immunofluorescent staining (using Cy2- and Cy3-conjugated secondary antibodies, in green and red, respectively) to reveal colocalization of the calcium binding proteins (CBPs; green) with enzyme proteins (EPs; red), glutamic acid decarboxylase (GAD; left panels) or phosphate activated glutaminase (PAG; right panels). CBP-immunostained cells are indicated by solid arrowheads, and EP immunostaining of the same neu rons is indicated by solid arrowheads for $\mathrm{EP}^{+}$neurons and open arrowheads for $\mathrm{EP}^{-}$neurons. Dual immunostaining for parvalbumin (Parv) and GAD $(\mathbf{A}, \mathbf{B})$ or Parv-PAG $(\mathbf{C}, \mathbf{D})$ revealed that most Parv ${ }^{+}$

$\mathrm{CBP}^{+}$cells were also immunopositive for GAD, ChAT, or PAG. In this examination by fluorescence microscopy, which did not allow processing by our image analysis system, we made no attempt to estimate cell numbers but simply calculated the proportions of double-labeled cell profiles, thereby permitting an estimation of the proportion of $\mathrm{CBP}^{+}$cells with the capacity to synthesize GABA, acetylcholine, or glutamate, as discussed below.

\section{Distribution of CBP-containing neurons}

$\mathrm{Parv}^{+}, \mathrm{Calb}^{+}$, and Calret ${ }^{+}$neurons varied in shape and size in the BF, as found by others in the medial septumdiagonal band nuclei (Kiss et al., 1990b, 1997), magnocellular basal nuclei (Celio, 1990; Chang and Kuo, 1991), and other forebrain structures (Freund and Buzsaki, 1996; DeFelipe, 1997; McDonald and Betette, 2001). Of the three groups of CPB-containing cells in the BF, the Parv ${ }^{+}$ neurons appeared to be the largest and most homogeneous in cell size, thus most closely resembling the prominent, magnocellular $\mathrm{GAD}^{+}$cells in the BF (Gritti et al., 1993).

The $\mathrm{CBP}^{+}$cell groups, like $\mathrm{GAD}^{+}$cells, are distributed coextensively with cholinergic cells throughout the $\mathrm{BF}$, thus substantiating reports by others of this distribution in the medial septum-diagonal band (Kiss et al., 1990b, 1997) and magnocellular basal nuclei of the rat (Celio, 1990; Chang and Kuo, 1991; Smith et al., 1994; Zaborszky et al., 1999). Whereas the distribution of the Parv ${ }^{+}$cells
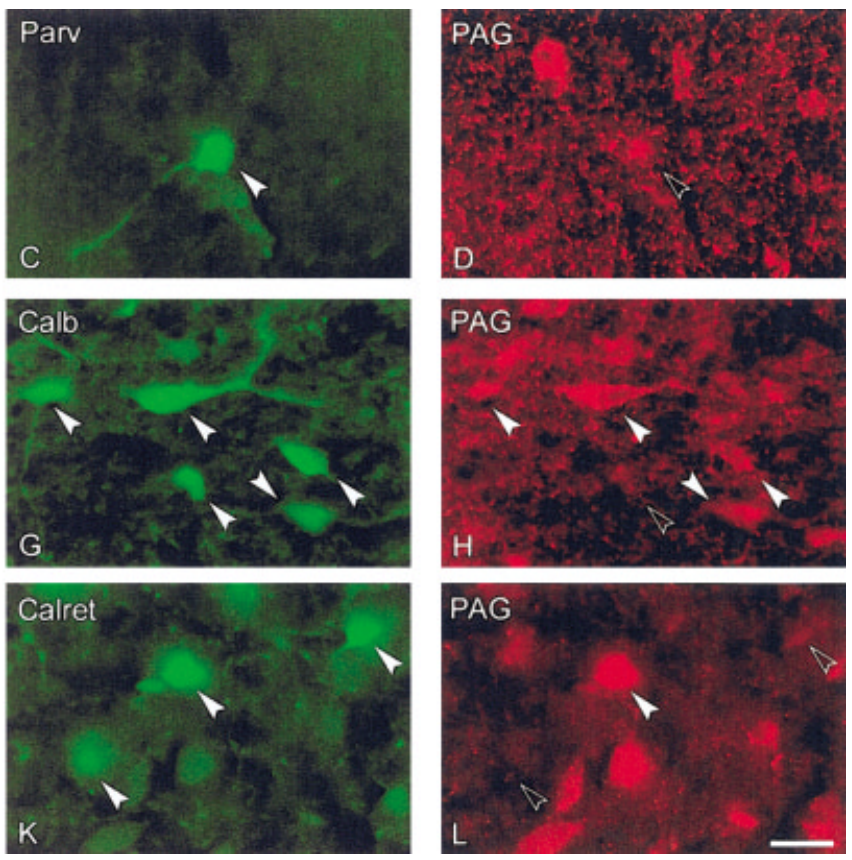

neurons (solid arrowheads in A) were $\mathrm{GAD}^{+}$(solid arrowheads in $\mathrm{B}$ ) and some Parv ${ }^{+}$neurons (solid arrowhead in C) were $\mathrm{PAG}^{-}$(open arrowhead in D). In sections dual immunostained for calbindin (Calb) and GAD $(\mathbf{E}, \mathbf{F})$ or Calb-PAG $(\mathbf{G}, \mathbf{H})$, most $\mathrm{Calb}^{+}$neurons (solid arrowheads in $\mathrm{E}$ ) were $\mathrm{GAD}^{-}$(open arrowheads in $\mathrm{F}$ ) and many $\mathrm{Calb}^{+}$ neurons (solid arrowheads in G) were $\mathrm{PAG}^{+}$(solid arrowheads in $\mathrm{H}$ ). In sections dual immunostained for calretinin (Calret) and GAD (I, J) or Calret-PAG $(\mathbf{K}, \mathbf{L})$, most Calret $^{+}$cells (solid arrowheads in I) were $\mathrm{GAD}^{-}$(open arrowheads in $\mathrm{J}$ ) and some Calret ${ }^{+}$cells (solid arrowheads in $\mathrm{K}$ ) were $\mathrm{PAG}^{+}$(solid arrowhead in L). Scale bar $=20 \mu \mathrm{m}$.

resembled that of the large $\mathrm{GAD}^{+}$cells, that of $\mathrm{Calb}^{+}$and Calret $^{+}$cells could not be simply likened to that of particular $\mathrm{GAD}^{+}$cells.

The total number of $\mathrm{CBP}^{+}$neurons (estimated at $\sim 117,000$ ) across the BF greatly exceeded that of the $\mathrm{GAD}^{+}$neurons $(\sim 39,000$; Gritti et al., 1993). A larger number of $\mathrm{CBP}^{+}$cells than of $\mathrm{GAD}^{+}$cells in the $\mathrm{BF}$ was noted by Zaborszky et al. (1999) and interpreted by them to mean that the number of $\mathrm{GAD}^{+}$cells had been previously underestimated by us. It appeared more probable to us that neurons in addition to $\mathrm{GAD}^{+}$neurons might be immunostained for CBPs, in particular for Calb and Calret. It was thus considered possible that Calb, contained in the largest number of cells, could also be contained in cholinergic neurons in the rat brain, as found in the monkey brain, despite claims to the contrary (Chang and Kuo, 1991; Ichitani et al., 1993). Given that the total number of $\mathrm{CBP}^{+}$neurons actually exceeded the total number of $\mathrm{GAD}^{+}$and $\mathrm{ChAT}^{+}$neurons across the $\mathrm{BF}$, it also appeared possible that other non-GABAergic and non-cholinergic neurons could contain CBPs.

\section{Distribution and number of cortically projecting CBP-containing neurons}

$\mathrm{Parv}^{+}, \mathrm{Calb}^{+}$, and Calret ${ }^{+}$neurons were retrogradely labeled from the cerebral cortex, and $\mathrm{Parv}^{+}$and $\mathrm{Calb}^{+}$ neurons were labeled in substantial numbers and thus 
potentially representing the GABAergic cortically projecting cell group, in contrast to Calret $^{+}$neurons, which were retrogradely labeled in numbers considered too small to pursue systematically. It was also apparent in different dual-immunostained series that different numbers of retrogradely labeled cells were apparent, suggesting a differential sensitivity in the dual immunostaining for reasons of antibody competition and/or displacement. Accordingly, total numbers of retrogradely labeled neurons differed between the Parv-CT and Calb-CT series of sections, which were thus considered independently for the calculation of proportions of retrogradely labeled cells. However, we cannot be sure that these proportions were not biased by the different sensitivities and thus should be considered as estimates. We also noted, as described previously, that, of the total population of retrogradely labeled cells, many were lightly retrogradely labeled with CT (Gritti et al., 1997), which is a very sensitive retrograde tracer. To be sure that the proportions of retrogradely cells calculated from the total numbers were not determined by a different density of retrograde labeling and thus projection, we also checked the proportions of the darkly retrogradely labeled cells. As established previously for the $\mathrm{GAD}^{+}$and $\mathrm{ChAT}^{+}$cells, the relative proportions did not change when comparing groups of darkly retrogradely labeled $\mathrm{CBP}^{+}$cells. We interpreted these results to indicate that, like the $\mathrm{GAD}^{+}$and $\mathrm{ChAT}^{+}$cells, the $\mathrm{Parv}^{+}$and $\mathrm{Calb}^{+}$cell groups comprise substantial proportions of cortically projecting neurons that provide a dense terminal innervation to a focused cortical target area in addition to a potentially more dispersed innervation to surrounding areas.

Although they varied to some degree in size and shape, $\mathrm{Parv}^{+}, \mathrm{Calb}^{+}$, and even the Calret ${ }^{+}$cortically projecting cells, like the GABAergic and cholinergic cortically projecting cells of the $\mathrm{BF}$, were generally medium to large in size. Despite differences attributed to variations in injection site and sensitivity of dual-immunostaining, retrogradely labeled $\mathrm{Parv}^{+}$cells and $\mathrm{Calb}^{+}$cells were approximately similarly distributed through the nuclei of the BF from the medial septum to the globus pallidus and overlapped in their distribution with that of GABAergic and cholinergic neurons of the $\mathrm{BF}$ projecting to the prefrontal and parietal cortexes (Gritti et al., 1997).

Through the medial septum to the globus pallidus, $\mathrm{Parv}^{+}$cortically projecting cells were present in substantial numbers, representing an average of $\sim 40-45 \%$ of the cortically projecting cells across the BF. This proportion was similar to, albeit greater than, that of the $\mathrm{GAD}^{+}$ cortically projecting neurons $(\sim 30-37 \%)$, as calculated in our previous study (Gritti et al., 1997). The results indicated that the $\mathrm{Parv}^{+}$cells could account for the GABAergic cortically projecting neurons of the BF. A similar conclusion was reached for the GABAergic neurons in the medial septum-diagonal band nuclei projecting to the hippocampus (Freund, 1989). Calb ${ }^{+}$cortically projecting cells also were present throughout the BF and accounted for $\sim 35 \%$ of cortically projecting neurons. These results were at odds with those of Smith et al. (1994) who did not find retrograde labeling of $\mathrm{Calb}^{+}$cells in the $\mathrm{BF}$. In view of our findings, such a negative result is surprising. It may be attributed to a lower sensitivity of the retrograde tracer (fluorogold) used or of the dual immunostaining for that tracer with Calb, which we also found to be less sensitive than that for CT-Parv. Given that the proportions of
$\mathrm{Calb}^{+}$and $\mathrm{Parv}^{+}$retrogradely labeled cells were $\sim 30-$ $45 \%$, it appeared that both could not correspond to the cortically projecting GABAergic cells or that Calb and Parv could be colocalized in the same magnocellular GABAergic neurons. This possibility cannot be ruled out because such colocalization has been documented in the amygdala (McDonald and Betette, 2001; McDonald and Mascagni, 2001). The Calret seen in a small number of retrogradely labeled cells also could be colocalized in the same cells, given evidence for colocalization of the three CBPs in neurons within certain forebrain regions (Wouterlood et al., 2000). However, such colocalization appears less likely in the BF neurons because it is relatively rare in other forebrain structures (Gulyas et al., 1991; Kubota et al., 1993; DeFelipe, 1997) and not at all within the medial septum-diagonal band nuclei (Kiss et al., 1997). Thus, $\mathrm{Parv}^{+}, \mathrm{Calb}^{+}$, and Calret ${ }^{+}$cortically projecting neurons likely corresponded predominantly to distinct cell subgroups and that those subgroups might not be all GABAergic.

\section{Colocalization of CBP with ChAT, GAD, or PAG in the BF}

Given the high degree of colocalization of Parv, Calb, and Calret with GAD or GABA in the neocortex, hippocampus, and the neostriatum (Kubota et al., 1993; Freund and Buzsaki, 1996; DeFelipe, 1997), we expected that such colocalization would also be frequent in the BF. Although this was the case for Parv, it was not for Calb or Calret. Of the $\mathrm{Parv}^{+}$cells throughout the BF, more than $90 \%$ were dual immunostained for GAD in the present study, indicating that the vast majority of $\mathrm{Parv}^{+}$cells has the capacity to synthesize GABA. In previous studies using dual immunostaining of anterogradely labeled septohippocampal fibers and terminals, it was believed that the Parv $^{+}$fibers emerging from the septum-diagonal band neurons contained GABA (Freund, 1989) and that the Parv $^{+}$neurons thus corresponded to the GABAergic septohippocampal projection neurons. Our present transmitter enzyme immunohistochemical and retrograde transport results also indicated that the $\mathrm{Parv}^{+} \mathrm{BF}$ neurons have the capacity to synthesize GABA and appear to correspond in large part to the basal cortical GABAergic projection neurons. In contrast, few $\mathrm{Calb}^{+}$cells $(<5 \%)$ contained GAD. Such minimal colocalization of Calb with $\mathrm{GAD}$ had been noted in the magnocellular basal nucleus (Smith et al., 1994). We also confirmed that $\mathrm{Calb}^{+}$neurons do not colocalize ChAT in the rat brain, although they had been found to do so in the primate brain (Chang and Kuo, 1991; Smith et al., 1994). We thus concluded from our retrograde and transmitter enzyme immunohistochemical results that Calb is predominantly contained within a distinct group of non-GABAergic, non-cholinergic basal cortical projection neurons. Like Calb ${ }^{+}$cells, few Calret ${ }^{+}$ cells $(<10 \%)$ contained GAD, leading us to conclude that Calret is contained predominantly in a distinct subgroup of non-cholinergic, non-GABAergic, caudally or locally projecting $\mathrm{BF}$ neurons.

Having recently established that the enzyme used in the synthesis of the transmitter glutamate, PAG, is localized in BF cortically projecting neurons (Manns et al., 2001), we sought to establish whether this enzyme was contained in the different $\mathrm{CBP}^{+}$cell groups. In studies within the neocortex, where all $\mathrm{CBP}^{+}$neurons also contained GAD, none contained PAG (Kaneko et al., 1992). The situation 
was different in the present study. Approximately half of the $\mathrm{Parv}^{+}$cells was also immunopositive for PAG, indicating that a proportion of these cells may have the potential to synthesize glutamate as a neurotransmitter. For GAD ${ }^{+}$ neurons, a similar proportion was found to contain PAG, indicating that, as in other areas of the brain, some $\mathrm{BF}$ neurons may have the capacity to synthesize GABA and glutamate (as discussed by Manns et al., 2001). Whether such cells use glutamate as a neurotransmitter can be determined only by immunostaining for the glutamate vesicular transporter proteins, which are evident in nerve terminals but not in cell bodies (Fremeau et al., 2001; B.E. Jones, unpublished observations). Among all Calb ${ }^{+}$cells, slightly less than half was immunopositive for PAG, indicating that a significant proportion of these cells have the capacity to synthesize glutamate as a neurotransmitter. Because most cortically projecting neurons were found to be $\mathrm{PAG}^{+}$(Manns et al., 2001), we concluded that the $\mathrm{Calb}^{+}$cortically projecting neurons most probably contain this enzyme and are thus potentially glutamatergic. Such cells may parallel in their projections and actions the $\mathrm{Calb}^{+}$glutamatergic neurons of the thalamus (Frassoni et al., 1997), which provide a widespread projection to the superficial layers of the cerebral cortex (Rausell and Jones, 1991; Jones, 1998). The vast majority of Calret ${ }^{+}$ neurons was immunopositive for PAG and not retrogradely labeled from the cortex, thus likely corresponding to glutamatergic neurons with caudally or locally directed projections. Such a possibility has been considered in the piriform and entorhinal cortex, where, in addition to containing glutamate, Calret ${ }^{+}$cells were found to provide asymmetric, and thus excitatory, synapses to local cortical neurons (Frassoni et al., 1998; Wouterlood et al., 2000).

\section{Functional significance of $\mathrm{CBP}$ content in BF cell groups}

In the hippocampus and neocortex, neurons containing the CBPs, which are commonly GABAergic interneurons, have been distinguished in their electrophysiologic properties from those lacking CBPs, i.e., the pyramidal neurons, by their frequently continuous and fast spiking discharge (Celio, 1986; Kawaguchi et al., 1987; Kawaguchi and Hama, 1988; Kawaguchi and Kubota, 1993; Freund and Buzsaki, 1996). Indeed, the CBPs serve to buffer $\mathrm{Ca}^{2+}$ and accordingly prevent $\mathrm{Ca}^{2+}$-activated $\mathrm{K}^{+}$currents from hyperpolarizing the membrane and inhibiting spike generation (Baimbridge et al., 1992). CBPs accordingly can also shape discharge patterns and in their absence or paucity permit phasic discharge by neurons ( $\mathrm{Li}$ et al., 1995). Throughout the forebrain, $\mathrm{Parv}^{+}$neurons are commonly fast spiking cells, as evident from in vitro and in vivo recording studies of identified neurons (Celio, 1986; Kawaguchi et al., 1987; Kawaguchi, 1993; Kawaguchi and Kubota, 1993; Sik et al., 1995). In the medial septumdiagonal band, Parv $^{+}$cells have been found to be fast spiking by in vitro recordings (Morris et al., 1999) and in the $\mathrm{BF}$ (in one cell) by in vivo recordings (Duque et al., 2000). In our in vivo recording studies, we identified a large number of cortically projecting $\mathrm{GAD}^{+}$neurons that discharge tonically at relatively high rates (average $>30$ $\mathrm{Hz}$ ) in association with cortical activation (Manns et al., 2000a) and thus could correspond to the cortically projecting, $\mathrm{Parv}^{+} \mathrm{BF}$ neurons identified here. $\mathrm{ChAT}^{+}$cells that do not contain the CBPs in the rat brain (Kiss et al., 1990b, 1997; Smith et al., 1994) discharge in a slow tonic manner and in a phasic bursting manner in association with cortical activation (Manns et al., 2000b). Other cortically projecting $\mathrm{BF}$ neurons that were $\mathrm{GAD}^{-}$and presumed noncholinergic cells discharged tonically at a moderate rate and may correspond to $\mathrm{Calb}^{+}$neurons (Manns et al., 2000a), which in other forebrain areas have been shown to discharge tonically (Li et al., 1995). Conversely, in the neocortex and hippocampus, $\mathrm{Calb}^{+}$neurons displayed phasic discharge properties in addition to fast spiking (Kawaguchi and Kubota, 1993; Sik et al., 1995; Freund and Buzsaki, 1996). Thus, recently discovered $\mathrm{GAD}^{-}$, $\mathrm{ChAT}^{-}, \mathrm{PAG}^{+}$cortically projecting $\mathrm{BF}$ neurons that were found to discharge at a moderate rate (average $\sim 20 \mathrm{~Hz}$ ) and to discharge in a phasic manner in association with cortical activation (Manns et al., 2000c) could also be $\mathrm{Calb}^{+}$cells.

CBPs also have the capacity to prevent or attenuate damage to cells due to excessive entry of $\mathrm{Ca}^{2+}$ during intense activity (Scharfman and Schwartzkroin, 1989). Such protection has been thought to underlie the selective survival and, conversely, selective vulnerability of neurons containing or lacking the different CBPs (for review, see Morrison et al., 1998). Given that $\mathrm{Parv}^{+}$and Calret ${ }^{+}$ neurons appear the most resistant and $\mathrm{Calb}^{+}$neurons the least among CBP-containing neurons in the cortex of patients with Alzheimer's disease, it is also possible that similarly different degrees of resistance would apply to BF neurons. Thus, $\mathrm{Parv}^{+}$GABAergic cortically projecting and Calret $^{+}$caudally or locally projecting neurons, documented here in the rat brain, might be expected to be more resistant than the Calb-containing cholinergic neurons in the human brain (Ichimiya et al., 1989) and other Calb ${ }^{+}$ potentially glutamatergic cortically projecting neurons therein.

Before gleaning more precise knowledge concerning the discharge properties and vulnerability to damage of the specific CBP-containing BF cell groups, the present results provide important information concerning the existence of noncholinergic, non-GABAergic basal cortical projection neurons and an immunohistochemical means of identifying them. From these results, it can be concluded that the basal cortical projection comprises, in addition to cholinergic neurons, likely GABAergic Parv ${ }^{+}$and possibly glutamatergic $\mathrm{Calb}^{+}$neurons. The existence of these noncholinergic basal cortical projection neurons may explain the finding that selective lesions of cholinergic neurons alone do not produce the serious attention and memory, as well as electroencephalographic, deficits of nonselective lesions of the entire BF cell population do in the rat (Dunnett et al., 1991; Lee et al., 1994; Voytko et al., 1994; Baxter et al., 1995). Accordingly, in addition to cholinergic and likely GABAergic Parv ${ }^{+}$neurons, possibly glutamatergic $\mathrm{Calb}^{+}$basal cortical projection neurons may play a critical role in modulating cortical activity and facilitating arousal, attention, and memory, functions that are greatly compromised with the degenerative changes occurring in the BF with Alzheimer's disease.

\section{ACKNOWLEDGMENTS}

We thank Naomi Takeda in Montreal for her assistance. We are most grateful to Dr. Takeshi Kaneko (Kyoto, Japan) for generously supplying the antibody. 


\section{LITERATURE CITED}

Abercrombie M. 1946. Estimation of nuclear population from microtome sections. Anat Rec 94:239-247.

Akiyama H, Kaneko T, Mizuno N, McGeer PL. 1990. Distribution of phosphate-activated glutaminase in the human cerebral cortex. J Comp Neurol 297:239-252.

Baimbridge KG, Celio MR, Rogers JH. 1992. Calcium-binding proteins in the nervous system. Trends Neurosci 15:303-308.

Baxter MG, Bucci DJ, Gorman LK, Wiley RG, Gallagher M. 1995. Selective immunotoxic lesions of basal forebrain cholinergic cells: effects on learning and memory in rats. Behav Neurosci 109:714-722.

Brashear HR, Zaborszky L, Heimer L. 1986. Distribution of GABAergic and cholinergic neurons in the rat diagonal band. Neuroscience 17 : $439-451$.

Cape EG, Jones BE. 2000. Effects of glutamate agonist versus procaine microinjections into the basal forebrain cholinergic cell area upon gamma and theta EEG activity and sleep-wake state. Eur J Neurosci 12:2166-2184.

Cape EG, Manns ID, Alonso A, Beaudet A, Jones BE. 2000. Neurotensininduced bursting of cholinergic basal forebrain neurons promotes gamma and theta cortical activity together with waking and paradoxical sleep. J Neurosci 20:8452-8461.

Celio MR. 1986. Parvalbumin in most gamma-aminobutyric acidcontaining neurons of the rat cerebral cortex. Science 231:995-997.

Celio MR. 1990. Calbindin D-28k and parvalbumin in the rat nervous system. Neuroscience 35:375-475.

Chang HT, Kuo H. 1991. Relationship of calbindin D-28k and cholinergic neurons in the nucleus basalis of Meynert of the monkey and the rat. Brain Res 549:141-145.

Coggeshall RE, Lekan HA. 1996. Methods for determining numbers of cells and synapses: a case for more uniform standards of review. J Comp Neurol 364:6-15.

DeFelipe J. 1997. Types of neurons, synaptic connections and chemical characteristics of cells immunoreactive for calbindin-D28K, parvalbu$\mathrm{min}$ and calretinin in the neocortex. J Chem Neuroanat 14:1-19.

Dunnett SB, Everitt BJ, Robbins TW. 1991. The basal forebrain-cortical cholinergic system: interpreting the functional consequences of excitotoxic lesions. Trends Neurosci 14:494-501.

Duque A, Balatoni B, Detari L, Zaborszky L. 2000. EEG correlation of the discharge properties of identified neurons in the basal forebrain. J Neurophysiol 84:1627-1635.

Frassoni C, Spreafico R, Bentivoglio M. 1997. Glutamate, aspartate and co-localization with calbindin in the medial thalamus. An immunohistochemical study in the rat. Exp Brain Res 115:95-104.

Frassoni C, Radici C, Spreafico R, de Curtis M. 1998. Calcium-binding protein immunoreactivity in the piriform cortex of the guinea-pig: selective staining of subsets of non-GABAergic neurons by calretinin. Neuroscience 83:229-237.

Fremeau RT Jr, Troyer MD, Pahner I, Nygaard GO, Tran CH, Reimer RJ, Bellocchio EE, Fortin D, Storm-Mathisen J, Edwards RH. 2001. The expression of vesicular glutamate transporters defines two classes of excitatory synapse. Neuron 31:247-260.

Freund TF. 1989. GABAergic septohippocampal neurons contain parvalbumin. Brain Res 478:375-381.

Freund TF, Buzsaki G. 1996. Interneurons of the hippocampus. Hippocampus 6:347-470.

Gritti I, Mainville L, Jones BE. 1993. Codistribution of GABA- with acetylcholine-synthesizing neurons in the basal forebrain of the rat. J Comp Neurol 329:438-457.

Gritti I, Mainville L, Jones BE. 1994. Projections of GABAergic and cholinergic basal forebrain and GABAergic preoptic-anterior hypothalamic neurons to the posterior lateral hypothalamus of the rat. J Comp Neurol 339:251-268.

Gritti I, Mainville L, Mancia M, Jones BE. 1997. GABAergic and other non-cholinergic basal forebrain neurons project together with cholinergic neurons to meso- and iso-cortex in the rat. J Comp Neurol 383 : 163-177.

Gritti I, Mainville L, Jones BE. 1999. Calcium binding proteins contained in cortically projecting and GABAergic basal forebrain neurons. Soc Neurosci Abstr 25:1135.

Gritti I, Manns ID, Mainville L, Jones BE. 2001. Calcium binding proteins reveal a distinct subgroup of cortically projecting basal forebrain neurons that may synthesize glutamate as a neurotransmitter. Soc Neurosci Abstr 27:675.
Guillery RW, Herrup K. 1997. Quantification without pontification: choosing a method for counting objects in sectioned tissues. J Comp Neurol 386:2-7.

Gulyas AI, Toth K, Danos P, Freund TF. 1991. Subpopulations of GABAergic neurons containing parvalbumin, calbindin D28k, and cholecystokinin in the rat hippocampus. J Comp Neurol 312:371-378.

Huerta PT, Lisman JE. 1993. Heightened synaptic plasticity of hippocampal CA1 neurons during a cholinergically induced rhythmic state. Nature 364:723-725.

Ichimiya Y, Emson PC, Mountjoy CQ, Lawson DE, Iizuka R. 1989 Calbindin-immunoreactive cholinergic neurones in the nucleus basalis of Meynert in Alzheimer-type dementia. Brain Res 499:402-406.

Ichitani Y, Tanaka M, Okamura H, Ibata Y. 1993. Cholinergic neurons contain calbindin D28k in the monkey medial septal nucleus and nucleus of the diagonal band: an immunohistochemical study. Brain Res 625:328-332.

Jones BE. 1993. The organization of central cholinergic systems and their functional importance in sleep-waking states. In: Cuello AC, editor. Cholinergic function and dysfunction. Progress in brain research. Amsterdam: Elsevier. p 61-71.

Jones BE. 2000. Basic mechanisms of sleep-wake states. In: Kryger MH, Roth T, Dement WC, editors. Principles and practice of sleep medicine. Philadelphia: Saunders. p 134-154.

Jones BE, Muhlethaler M. 1999. Cholinergic and GABAergic neurons of the basal forebrain: role in cortical activation. In: Lydic R, Baghdoyan $\mathrm{H}$, editors. Handbook of behavioral state control: cellular and molecular mechanisms. Boca Raton: CRC Press. p 213-233.

Jones EG. 1998. Viewpoint: the core and matrix of thalamic organization. Neuroscience 85:331-345.

Kaneko T, Mizuno N. 1988. Immunohistochemical study of glutaminasecontaining neurons in the cerebral cortex and thalamus of the rat. J Comp Neurol 267:590-602.

Kaneko T, Mizuno N. 1994. Glutamate-synthesizing enzymes in GABAergic neurons of the neocortex: a double immunofluorescence study in the rat. Neuroscience 61:839-849.

Kaneko T, Itoh K, Shigemoto R, Mizuno N. 1989. Glutaminase-like immunoreactivity in the lower brainstem and cerebellum of the adult rat. Neuroscience 32:79-98.

Kaneko T, Nakaya Y, Mizuno N. 1992. Paucity of glutaminaseimmunoreactive nonpyramidal neurons in the rat cerebral cortex. J Comp Neurol 322:181-190.

Kawaguchi Y. 1993. Physiological, morphological, and histochemical characterization of three classes of interneurons in rat neostriatum. J Neurosci 13:4908-4923.

Kawaguchi Y, Hama K. 1988. Physiological heterogeneity of nonpyramidal cells in rat hippocampal CA1 region. Exp Brain Res 72:494-502.

Kawaguchi Y, Kubota Y. 1993. Correlation of physiological subgroupings of nonpyramidal cells with parvalbumin- and calbindin ${ }_{\mathrm{d} 28 \mathrm{k}}$-immunoreactive neurons in layer V of rat frontal cortex. J Neurophysiol 70:387-396.

Kawaguchi Y, Katsumaru H, Kosaka T, Heizmann CW, Hama K. 1987. Fast spiking cells in rat hippocampus (CA1 region) contain the calciumbinding protein parvalbumin. Brain Res 416:369-374.

Kilgard MP, Merzenich MM. 1998. Cortical map reorganization enabled by nucleus basalis activity. Science 279:1714-1718.

Kiss J, Magloczky Z, Somogyi J, Freund TF. 1997. Distribution of calretinin-containing neurons relative to other neurochemically identified cell types in the medial septum of the rat. Neuroscience 78:399410.

Kiss J, Patel AJ, Baimbridge KG, Freund TF. 1990a. Topographic localization of neurons containing parvalbumin and choline acetyltransferase in the medial septum-diagonal band region of the rat. Neuroscience 36:61-72.

Kiss J, Patel AJ, Freund TF. 1990b. Distribution of septohippocampal neurons containing parvalbumin or choline acetyltransferase in the rat brain. J Comp Neurol 298:362-372.

Kubota Y, Mikawa S, Kawaguchi Y. 1993. Neostriatal GABAergic interneurones contain NOS, calretinin or parvalbumin. Neuroreport 5:205208

Lee MG, Chrobak JJ, Sik A, Wiley RG, Buzsaki G. 1994. Hippocampal theta activity following selective lesion of the septal cholinergic system. Neuroscience 62:1033-1047.

Li Z, Decavel C, Hatton GI. 1995. Calbindin-D28k: role in determining intrinsically generated firing patterns in rat supraoptic neurones. J Physiol 488:601-608.

Manns ID, Alonso A, Jones BE. 2000a. Discharge profiles of juxtacellularly 
labeled and immunohistochemically identified GABAergic basal forebrain neurons recorded in association with the electroencephalogram in anesthetized rats. J Neurosci 20:9252-9263.

Manns ID, Alonso A, Jones BE. 2000b. Discharge properties of juxtacellularly labeled and immunohistochemically identified cholinergic basal forebrain neurons recorded in association with the electroencephalogram in anesthetized rats. J Neurosci 20:1505-1518.

Manns ID, Alonso A, Jones BE. 2000c. Rhythmic discharge of identified cholinergic, GABAergic and glutamatergic juxtacellularly labelled and immunohistochemically identified basal forebrain neurons in relation to EEG activity. Soc Neurosci Abstr 26:1514.

Manns ID, Mainville L, Jones BE. 2001. Evidence for glutamate, in addition to acetylcholine and GABA, neurotransmitter synthesis in basal forebrain neurons projecting to the entorhinal cortex. Neuroscience 107:249-263.

McDonald AJ, Betette RL. 2001. Parvalbumin-containing neurons in the rat basolateral amygdala: morphology and co-localization of calbindin$\mathrm{D}(28 \mathrm{k})$. Neuroscience 102:413-425.

McDonald AJ, Mascagni F. 2001. Colocalization of calcium-binding proteins and GABA in neurons of the rat basolateral amygdala. Neuroscience 105:681-693.

Metherate R, Cox CL, Ashe JH. 1992. Cellular bases of neocortical activation: modulation of neural oscillations by the nucleus basalis and endogenous acetylcholine. J Neurosci 12:4701-4711.

Metherate R, Tremblay N, Dykes RW. 1988. Transient and prolonged effects of acetylcholine on responsiveness of cat somatosensory cortical neurons. J Neurophysiol 59:1253-1276.

Morris NP, Harris SJ, Henderson Z. 1999. Parvalbumin-immunoreactive, fast-spiking neurons in the medial septum/diagonal band complex of the rat: intracellular recordings in vitro. Neuroscience 92:589-600.

Morrison BM, Hof PR, Morrison JH. 1998. Determinants of neuronal vulnerability in neurodegenerative diseases. Ann Neurol 44:S32-S44.

Muir JL, Everitt BJ, Robbins TW. 1994. AMPA-induced excitotoxic lesions of the basal forebrain: a significant role for the cortical cholinergic system in attentional function. J Neurosci 4:2313-2326.

Oertel WH, Mugnaini E, Schmechel DE, Tappaz ML, Kopin IJ. 1982. The immunocytochemical demonstration of gamma-aminobutyric acidergic neurons: methods and application. In: Chan-Palay V, Palay SI, editors. Cytochemical methods in neuroanatomy. New York: Alan R. Liss. p 297-329.

Paxinos G, Watson C. 1986. The rat brain in stereotaxic coordinates Sydney: Academic Press.

Rausell E, Jones EG. 1991. Chemically distinct compartments of the thalamic VPM nucleus in monkeys relay principal and spinal trigeminal pathways to different layers of the somatosensory cortex. J Neurosci 11:226-237.

Scharfman HE, Schwartzkroin PA. 1989. Protection of dentate hilar cells from prolonged stimulation by intracellular calcium chelation. Science 246:257-260.

Sik A, Penttonen M, Ylinen A, Buzsaki G. 1995. Hippocampal CA1 interneurons: an in vivo intracellular labeling study. J Neurosci 15:66516665.

Smith G. 1988. Animal models of Alzheimer's disease: experimental cholinergic denervation. Brain Res 472:103-118.

Smith ML, Hale BD, Booze RM. 1994. Calbindin- ${ }_{28 k}$ immunoreactivity within the cholinergic and GABAergic projection neurons of the basal forebrain. Exp Neurol 130:230-236.

Voytko ML, Olton DS, Richardson RT, Gorman LK, Tobin JR, Price DL. 1994. Basal forebrain lesions in monkeys disrupt attention but not learning and memory. J Neurosci 14:167-186.

Wouterlood FG, van Denderen JC, van Haeften T, Witter MP. 2000. Calretinin in the entorhinal cortex of the rat: distribution, morphology, ultrastructure of neurons, and co-localization with gammaaminobutyric acid and parvalbumin. J Comp Neurol 425:177-192.

Zaborszky L, Pang K, Somogyi J, Nadasdy Z, Kallo I. 1999. The basal forebrain corticopetal system revisited. Ann N Y Acad Sci 877:339-367. 